\title{
The Determinants of Innovation Performance; An Income Based Cross-Country Comparative Analysis Using Global Innovation Index(GII)
}

\author{
Adisu Fanta Bate ( $\nabla$ adisufanta@gmail.com ) \\ University of Pecs https://orcid.org/0000-0003-2729-3934 \\ Esther Wanjiru Wachira \\ University of Pecs: Pecsi Tudomanyegyetem \\ Danka Sándor \\ University of Pecs: Pecsi Tudomanyegyetem
}

\section{Research}

Keywords: Innovation, innovation inputs, innovation outputs, determinants of innovation, business sophistication, market sophistication, institutions, infrastructure, human capital, and R\&D

Posted Date: October 13th, 2021

DOl: https://doi.org/10.21203/rs.3.rs-955254/v1

License: (c) (i) This work is licensed under a Creative Commons Attribution 4.0 International License. Read Full License 


\section{Abstract}

Purpose: - Despite the dearth of research on innovation performance, the key determinants of innovation performance are still blurred. Besides, comparative research on the determinants of innovation performance among countries at different income levels: high-income, upper-middle-income, lower-middle-income, and lowincome, is not common. This study is, therefore, aimed to bridge this research gap by considering the innovation performance of 63 countries.

Methodology: - Participating countries were purposefully selected from the Global Innovation Index (GII) dataset. Multistage analyses were conducted: first, a linear regression was run to identify the most decisive pillars; then, stepwise regression was applied to identify the best predicting model of innovation performance; thirdly, to examine the variation in innovation performance and figure out key determinants in each country groups, the ANOVA analysis was done.

Results: - Human capital and research, infrastructure, and business sophistication are the key pillars determining innovation performance in general. The best predicting variables are innovation linkage \& knowledge absorption (both pertaining to business sophistication), R\&D and infrastructure (inculcating both physical and digital). The human capital that promotes R\&D activities is the biggest bottleneck hampering promotion of innovation in the countries and firms at lower-middle income category, whereas innovation linkage in a high-income category and both human capital that promotes R\&D activities and innovation linkage in an upper-middle income category. Hence, countries and firms in these income categories should give priorities accordingly to these decisive bottlenecks hindering the innovation performance.

Implication: - The result implies that country's economic growth can be defined by the level of innovation performance and the challenges of innovation vary as per the countries' development stage. Accordingly, bottleneck factors need to be identified \& addressed properly in a policy direction first at firm level and then at country level.

Originality/Value: - The study claims to have extended the horizon of understanding on determinants of innovation across countries and revealed the most crucial factors in each category of countries. Further empirical comparative research can be done by stratifying firms as SMEs and Large firms in each category of countries.

\section{Introduction}

Innovation has been defined as the introduction of new products or services, new processes, opening up new markets, use of new resources to create value in the market (Wang \& Ahmed, 2017; Obunike \& Udu, 2019). Scholars classify innovation as technological and non-technological innovativeness (Tseng, 2014; Rahman et al., 2016). Using the combination of technological innovation and non-technological innovation makes businesses more competitive (Zawawi et al., 2016). According to Pisano (2015), there are four types of innovation namely disruptive, architectural, routine, and radical innovation. Damanpour and Wischnevsky (2006) argue that businesses and startups should focus more on radical innovation while large firms should focus more on a routine or incremental innovation. 
In general, new business ventures are termed as the driver of innovation and the creation of wealth. New and

relatively small firms can be seen as the major engine towards employment opportunities, incentives towards innovation, job creation, and the improvement of the well-being of the residents (Sembiring, 2016; Tsatsenko et al., 2020). Hence, it has been seen that countries place more emphasis on encouraging the growth of these small and new firms, as a means, to reduce unemployment and poverty.

However, despite their positive contribution towards economic development and employment, new and small businesses are faced with the challenge of innovation to stay afloat. The level of innovation in the small or new businesses determines either their success or failure (Frambach, 1993). Notably, most of the small or new businesses fail to innovate (Ndesaulwa \& Kikula, 2016). This failure to innovate has its implications such as reduced competitiveness, becoming less aware of the changes in the environment, and innovative solutions, hence results in poor performance (Hausman, 2005; Farsi \& Toghraee 2015 and Mustafa \& Yaakub, 2018). To remain competitive, the business must continuously innovate to ensure that its products or services match up with the changing technology and markets (Hutt and Speh 2010; Pisano 2015).

Regardless of the size of business, innovation is essential for stimulating the growth and development of both developing and developed countries (Barrichello et al., 2020). Previous literature has focused on determinants of innovation (Barrichello et al., 2020; Protogerou et al., 2017; Qureshi et al., 2021), innovation challenges per country (Farsi \& Toghraee, 2015; Uvarova \& Vitola, 2019), dynamics of innovation (Sharif et al., 2021). Despite the dearth of research on the concept of innovation, the key determinants of innovation performance are still blurred. Also, as far as the knowledge of the researchers is concerned, no comparative research is found on the determinants of innovation performance among country groups at different incomelevel: high-income, upper-middle-income, lower-middle-income, and low-income countries, whose classification is based on world bank.

This study, therefore, aims to bridge this research gap by considering the innovation performance of 63 countries. The multistage analyses were conducted using linear regression, stepwise regression, and ANOVA model. The results indicate that human capital and research, infrastructure, and business sophistication as the key pillars determining innovation performance. The study further reveals that human capital which promotes R\&D activities is the biggest bottleneck that hamper the promotion of innovation in a lower-middle income category, whereas innovation linkage in a high-income category and both human capital that promotes R\&D activities and innovation linkage in an upper-middle income category. The remaining sections of the paper present literature review (2), methodology (3), data analysis and results (4), discussion (5) and conclusion (6) and implication and limitation (7), respectively.

\section{Literature Review And Hypothesis Development 2.1. Determinants of Innovation}

The notion of innovation has been widely studied since the 1970s. Early researchers focused on the concept of innovation and scales for the measurements (Hurt, Joseph, and Cook 1977; Midgley and Dowling 1978; Subramanian, 1996). Consequently, research on innovation broadened to areas such as customer 
innovativeness, the impact of innovativeness (Venkatraman, 1991; Roehrich,2004 \& Hult et al., 2004) and determinants of innovation (Romijn \& Albaladejo, 2002 and Bhattacharya \& Bloch, 2004).

Furthermore, academic scholars have expanded their research on the determinants of innovation. For instance, Pertuz et al., (2018) argue that organizational structures, work climate, development of knowledge, and well-being of human resources are some of the factors that determine the innovation capacity of medium-sized firms. Additionally, Restrepo-Morales et al.,(2019) identified R\&D activities and alliances as the determinants of innovativeness of SMEs in Colombia. While Babuchowska \& Marks-Bielska (2021) reveal that streamlining of work, improvement in quality, and compliance with the requirements as some of the determinants of innovation in dairy farms in Poland. Moreover, Kireyeva et al., (2021) identify the age of the company, type, sector, R\&D, and technology as having a positive influence on the organization's tendency to innovate. Interestingly, competitors in the market and the location (region) had a negative effect on the tendency to innovate (Kireyeva et al., 2021). Table 2.1 shows the empirical studies on determinants of innovation and measures of innovation performance in different countries. 
Table 2.1

Empirical analysis on the determinants of innovation

\begin{tabular}{|c|c|c|c|c|}
\hline Studies & $\begin{array}{l}\text { Measures of } \\
\text { Innovation }\end{array}$ & $\begin{array}{l}\text { Country } \\
\text { coverage }\end{array}$ & Key findings & Firm size/type \\
\hline $\begin{array}{l}\text { Sudolska } \\
\text { and } \\
\text { Łapińska, } \\
(2020)\end{array}$ & $\begin{array}{l}\text { Innovation } \\
\text { outputs }\end{array}$ & Poland & $\begin{array}{l}\text { The capability of innovation is } \\
\text { determined by inter-organization } \\
\text { capability, hiring employees in R\&D } \\
\text { and increasing firms' internal } \\
\text { expenditure on R\&D. }\end{array}$ & $\begin{array}{l}\text { Manufacturing } \\
\text { sectors }\end{array}$ \\
\hline $\begin{array}{l}\text { Ndesaulwa } \\
\text { \& Kikula, } \\
(2016)\end{array}$ & $\begin{array}{l}\text { Infrastructure, } \\
\text { R\&D } \\
\text {, Market } \\
\text { Conditions }\end{array}$ & Tanzania & $\begin{array}{l}\text { SMEs in these countries face the } \\
\text { challenge of gaining entrance into the } \\
\text { new markets, and their presence in the } \\
\text { market has little or no influence on the } \\
\text { market prices as its market prices are } \\
\text { influenced by larger firms }\end{array}$ & SME \\
\hline $\begin{array}{l}\text { Uvarova \& } \\
\text { Vitola, } \\
(2019)\end{array}$ & $\begin{array}{l}\text { Policies } \\
\text { Knowledge and } \\
\text { skills } \\
\text { Cooperation and } \\
\text { networking }\end{array}$ & $\begin{array}{l}\text { European } \\
\text { countries }\end{array}$ & $\begin{array}{l}\text { inappropriate innovation policies, lack } \\
\text { of skills and knowledge, inability to } \\
\text { hire skilled workforce, inadequacies in } \\
\text { the environment for innovation and } \\
\text { competitiveness }\end{array}$ & Rural SMEs \\
\hline $\begin{array}{l}\text { Farsi \& } \\
\text { Toghraee, } \\
(2014)\end{array}$ & $\begin{array}{l}\text { R\&D } \\
\text { Human Capital } \\
\text { Regulation and } \\
\text { Policy } \\
\text { Market } \\
\text { Information } \\
\text { Infrastructure } \\
\text { (Technology) }\end{array}$ & Iran & $\begin{array}{l}\text { lack of managerial training and } \\
\text { experience, lack of credit, changes in } \\
\text { technology, policies, and regulations, } \\
\text { and inadequate market information }\end{array}$ & SMEs \\
\hline $\begin{array}{l}\text { Agwu, } \\
(2014)\end{array}$ & $\begin{array}{l}\text { Infrastructure } \\
\text { Skills }\end{array}$ & Nigeria & $\begin{array}{l}\text { inadequate social infrastructures, } \\
\text { taxation, inadequate financing, and } \\
\text { lack of managerial skills }\end{array}$ & SMEs \\
\hline $\begin{array}{l}\text { Gachara, } \\
(2017)\end{array}$ & $\begin{array}{l}\text { Knowledge } \\
\text { Resources } \\
\text { Technology } \\
\text { Regulations and } \\
\text { policy }\end{array}$ & Kenya & $\begin{array}{l}\text { knowledge challenges, resources } \\
\text { challenge, technology challenges, } \\
\text { legal and policies challenges, and } \\
\text { environmental challenges faced by } \\
\text { SMEs in both developed and } \\
\text { developing countries }\end{array}$ & SME \\
\hline $\begin{array}{l}\text { Stern et al., } \\
(2000)\end{array}$ & $\begin{array}{l}\text { International } \\
\text { patents granted } \\
\text { by USA patent } \\
\text { office }\end{array}$ & $\begin{array}{l}17 \text { OECD } \\
\text { countries }\end{array}$ & $\begin{array}{l}\text { Innovative capacity is characterized } \\
\text { by R\&D manpower and spending } \\
\text { policies such as intellectual property, } \\
\text { trade, openness, the share of research } \\
\text { by the academic sector, and } \\
\text { knowledge stock }\end{array}$ & $\begin{array}{l}\text { Both large and } \\
\text { SMEs }\end{array}$ \\
\hline
\end{tabular}




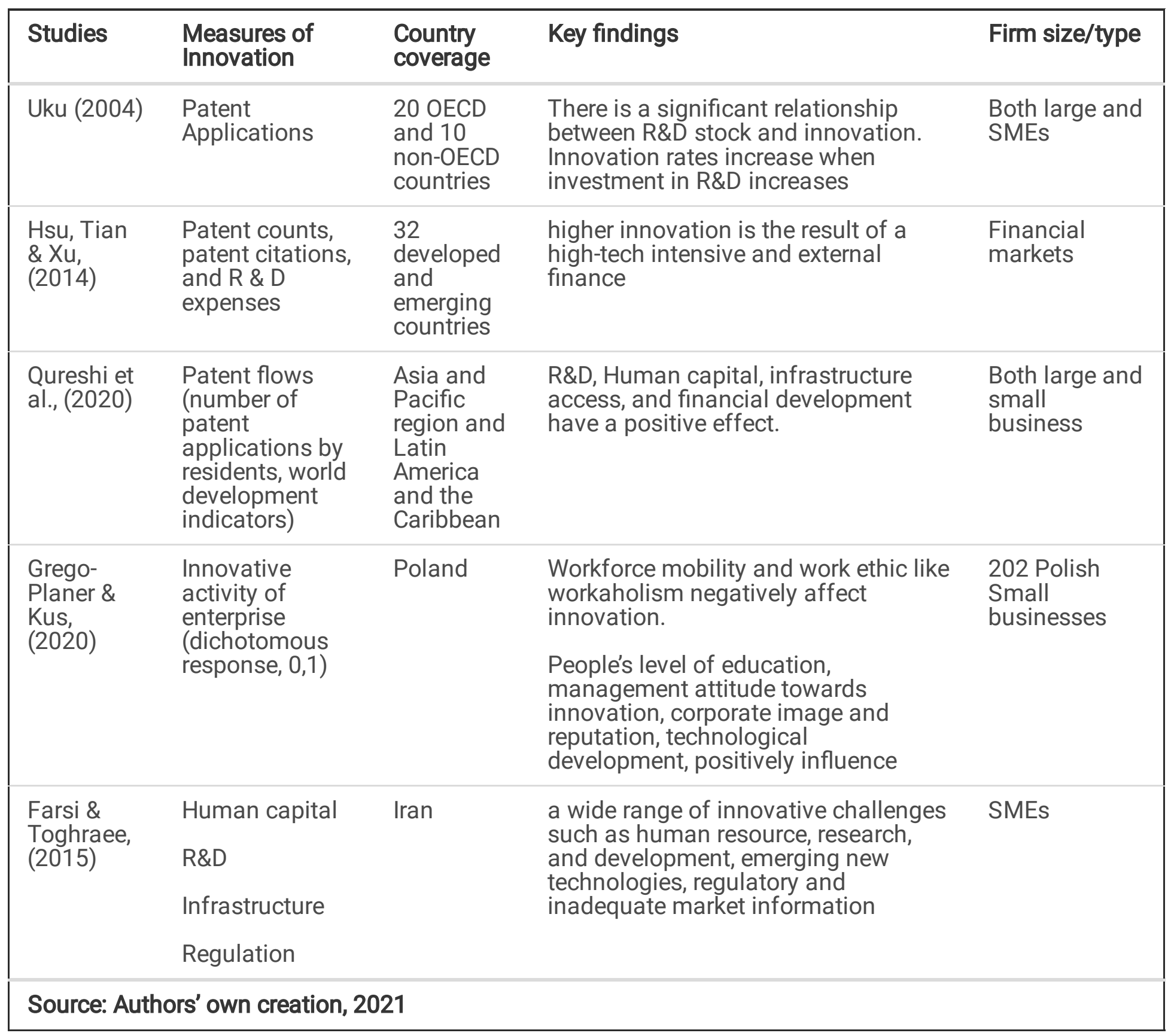

\subsection{Hypothesis Development}

Though various sources, as shown in Table 2.1., reveal a diverse set of determinants of innovation, Global Innovation Index, which is adopted for this study, summarizes them all under five pillars: institutions, human capital and research, infrastructure, market sophistication and business sophistication. Tracing on the literature, the association between these pillars and innovation performance is hypothesized in the succeeding subsections.

\subsubsection{Institutions and innovation performance}

Institutions can be classified as either formal institutions or informal institutions (Minto-Coy, \& McNaughton 2016; Okrah \& Hajduk-Stelmachowicz, 2020). Property rights, contracts, policies, regulations, laws, and constitution are formal institutions while informal institutions refer to culture and society norms that rule the 
operations of the businesses (Berman, 2013; Minto-Coy, \& McNaughton 2016). A country with weak institutional factors or where the institutional factors put in place are not considered hinders innovation by deteriorating the confidence of the investors, customers, and industries (Jovovic et al., 2017; SzalachaJarmużek \& Pietrowicz, 2018). Additionally, the political environment of a country determines the efficiency of innovation. Hence, increasing the investment attractiveness of locally owned firms by the assistance from the local authorities helps to create a good connection for innovation (Yachmeneva \& Vol's'ka, 2014).

According to Oluwatobi et al. (2016), the quality of institutions (Government effectiveness, political stability, rule of law, and regulatory quality) affects the output of innovation in Sub Sahara Africa. In support of these findings, a study by Okrah \& Hajduk-Stelmachowicz (2020) concludes that good institutional environments foster innovativeness. For instance, a favorable political climate encourages small businesses and entrepreneurs to explore various opportunities and at the same time, the confidence of the public in their political system encourages innovativeness (Okrah \& Hajduk-Stelmachowicz, 2020). Moreover, a sound legal and regulatory structure fosters the growth and innovativeness of small businesses (Nyarku \& Oduro, 2018). Further, a study by Wang et al., (2020) revealed that firms in China with high government affiliation enhance their innovativeness. The study also argued that the government affiliation for innovativeness largely depends on the intensity of the protection of intellectual property by the legal institutions (Wang et al., 2020). In accord with these facts, we hypothesize as follows:

$H_{1}$ : There is a statistically significant effect and positive relationship between institutions and innovation performance

\subsubsection{Human Capital, Research and Development and Innovation Performance}

Competent human capital with educational background and adequate skills are important for the growth of new and young businesses. Basic education and continuous investment in the development of human resources are essential to motivate innovativeness, especially for new businesses. According to Oluwatobi et al., (2016), human capital is viewed as an essential determinant of innovation across countries. You et al. (2021) argue that human capital stimulates innovation since education improves employee skills and their ability to acquire knowledge. Moreover, educated employees combine the knowledge acquired in education in unique ways to achieve innovation (You et al., 2021).

Research reveals a positive relationship between human capital and innovativeness. Farace \& Mazzotta (2015) concludes that there is a positive relationship between human capital and the innovativeness of SMEs in Italy. This argument was in line with Protogerou et al.(2017) study which found previous exposure to R\&D, educational background, diversity of the team as internal factors that determine the innovativeness of young firms in Europe. Additionally, the study by Wang et al., (2020) reveal that human capital and R\&D as some of the essential factors that explain innovativeness particularly technological innovation in advanced economies. While, Qureshi et al., (2020) finds a positive and significant relationship between R\&D and innovation in the Asia-Pacific countries but not in Latin America and the Caribbean countries. The study also found a positive effect of education on innovation in the Asia-Pacific countries as well as the Latin America 
and the Caribbean countries (Qureshi et al., 2021). Additionally, You et al., (2021) finds a positive effect of human capital on firm's innovation in China. Therefore, relying on these facts we hypothesize as follows:

$\mathrm{H}_{2}$ : There is a statistically significant effect and positive relationship between human capital and innovation performance

\subsubsection{Infrastructure and Innovation Performance}

A healthy and established technological and physical infrastructure is essential in the enhancing innovation of businesses. According to Pan et al. (2021), a good technology infrastructure boosts technological innovation and hence indirectly promoting the economic development of countries.

A study by Jabbouri et al., (2016) found a positive and significant relationship between technological infrastructure and innovation performance in Iraq. Tsetim et al., (2020) indicate that infrastructural dimensions which include technology, structure, and culture had a significant relation to the innovativeness of SMEs in Nigeria. Additionally, Qureshi et al., (2020) argue that a positive and significant relationship between infrastructure access and innovation in the Asia-Pacific countries but not in Latin America and the Caribbean countries. In China, Pan et al., (2021) pinpoint an inverted U-type nonlinear influence of technology infrastructure on the local innovation capability.

$H_{3}$ : There is a statistically significant effect and positive relationship between infrastructure and innovation performance.

\subsubsection{Market Sophistication and Innovation Performance}

This study views market sophistication in terms of the availability of credit facilities that support the innovation of businesses, access of businesses to the international markets, competition, and the ease of protecting the small investors to do business. New businesses face intense competitive pressure from large and established firms, therefore, should focus more on innovation to deal with the challenge of the everchanging and dynamic business environment. Organizational innovativeness is mainly benchmarked against their competitors to develop unique products (Im \& Workman, 2004). Additionally, continuous benchmarking with rival companies heightens innovativeness (Pesämaa, Shoham, Wincent, and Ruvio, 2013).

Despite the competition, small and new businesses especially in developed countries are faced with the challenge of accessing credit (Giang et al., 2019). Academic scholars have argued that access to finance plays an important role in the innovativeness of firms (Osano \& Languitone, 2015 and Fernandez,2017). Related literature by Wellalage \& Fernandez, (2019) on innovation and SME finance in developing countries revealed a positive relationship between financing (formal and informal) and the innovativeness (product and process) of a firm. It is against this background that the study aims to investigate the relationship between market sophistication and innovativeness of SMEs.

$H_{4}$ : There is a statistically significant effect and positive relationship between market sophistication and innovation performance.

\subsubsection{Business Sophistication and Innovation Performance}


This study views business sophistication in terms of knowledge workers, innovation linkages, and knowledge absorption. Razavi et al., (2012) and Dima et al., (2018) refer to business sophistication as the quality of business networks and the quality of business strategies and operations. This is in line with Kirikkaleli \& Ozun, (2019) who argue that business sophistication focuses on the general quality of the country's business networks, quality of individual business strategies and operations. Moreover, business sophistication can be viewed in terms of the knowledge of the workers. Knowledge is a very crucial element in the development and growth of businesses across the globe. In the current era of globalization, investing in a more knowledgeable workforce and management of this knowledge (Hassan \& Raziq, 2019) gives businesses a competitive advantage in terms of innovation. According to Kirikkaleli \& Ozun (2019), in innovation-driven economies, business sophistication and innovation are seen as the essential components of competitiveness.

A study by Razavi et al., (2012) found a significant and positive relationship between innovation and business sophistication. Protogerou et al., (2017) revealed that external factors such as technology collaborations and networking with universities are crucial in explaining the innovation of young firms in Europe. Additionally, the interconnection of businesses with government and research institutions and customers have been termed as the most significant linkages that boost innovation (Ortega \& Serna, 2020). A study by Kirikkaleli \& Ozun (2019) found a positive link between business sophistication and innovation capacity in OECD countries. Following this argument, we hypothesize as follows:

$H_{5}$ : There is a statistically significant relationship between business sophistication and innovation performance.

\subsubsection{Per Capita Income and Innovation Performance}

According to Zanello et al., (2016), the intensity of innovation, types of innovation, and determinants of innovation vary based on country context and its level of development. For instance, in low-income countries, the assimilation and adoption of new technologies are important foundations for the innovation process. This has been furtherly explained by Qurashi, et al. (2021) that R\&D has a positive and significant effect on innovation in the Asia Pacific region, but not in Latin America and the Caribbean countries. Besides, infrastructure access has a positive significant influence on innovation only in Asia and the Pacific region, whereas financial development affects innovation only in Latin America and the Caribbean. Education level is the only variable that has a significant effect on innovation in both regions. Therefore, this study is intended to investigate the variation of determinants based on the level of economic development: lower-middleincome, upper-middle-income, and high-income countries.

H6: There is a statistically significant variation in determinants of innovation among countries with different income levels.

H6a: There is a statistically significant variation of determinants of innovation between lower-middle-income and upper-middle-income countries.

H6b: There is a statistically significant variation of determinants of innovation between upper-middle-income and high-income countries. 


\section{Methodology}

The study applies a quantitative research design. The cross-sectional data were obtained from the website of the World Intellectual Property Organization (WIPO): Global Innovation Index (GII) 2020. The analysis was made at the country level to identify the determinants of innovation from a broad and national perspective. The country-level data which of the index allows us to investigate the inputs of innovation which are commonly known as determinants of innovation on one side and the outputs of innovation on the other side. The country selection was based on data accuracy in the dataset to incorporate only those countries having all, or missing a very little of, the required data in the measurement. A total of 63 (48\% of 131 countries) countries, see appendix Table 3.2., have been included in the study and represent all economic levels and regions in the world. Linear regression was run to identify significant determinants at pillar level and their effect on innovation outputs. To find out the best predicting model, the stepwise multiple regression analysis was conducted with the common stepping method criteria (the probability of $F$ is equal to 0.05 for entry and 0.1 for removal) at variable level. One-way ANOVA was conducted to single out the variation innovation input and output performance among countries in three income-based groups. The bottleneck in each category is identified and illustrated in histogram.

Table 3.2. Per-capita income based country classification (subjects of this study) 


\begin{tabular}{|c|c|c|c|c|c|}
\hline High-income & Code & Upper-middle income & Code & Lower-middle income & code \\
\hline Australia & 1 & Malaysia & 2 & Philippines & 3 \\
\hline Austria & 1 & Thailand & 2 & Ukraine & 3 \\
\hline Belgium & 1 & China & 2 & Egypt & 3 \\
\hline Canada & 1 & Algeria & 2 & Ethiopia & 3 \\
\hline Cyprus & 1 & Argentina & 2 & Ghana & 3 \\
\hline Czech Republic & 1 & Brazil & 2 & India & 3 \\
\hline Estonia & 1 & Colombia & 2 & Indonesia & 3 \\
\hline Hungary & 1 & Costa Rica & 2 & Kenya & 3 \\
\hline Italy & 1 & Kazakhstan & 2 & Morocco & 3 \\
\hline Latvia & 1 & Mexico & 2 & Tunisia & 3 \\
\hline Lithuania & 1 & Peru & 2 & & \\
\hline Malta & 1 & Romania & 2 & & \\
\hline New Zealand & 1 & Russian Federation & 2 & & \\
\hline Norway & 1 & Serbia & 2 & & \\
\hline Poland & 1 & South Africa & 2 & & \\
\hline Portugal & 1 & Turkey & 2 & & \\
\hline Slovakia & 1 & Bulgaria & 2 & & \\
\hline Slovenia & 1 & & & & \\
\hline Spain & 1 & & & & \\
\hline Denmark & 1 & & & & \\
\hline Finland & 1 & & & & \\
\hline France & 1 & & & & \\
\hline Germany & 1 & & & & \\
\hline Israel & 1 & & & & \\
\hline Japan & 1 & & & & \\
\hline Luxembourg & 1 & & & & \\
\hline Netherlands & 1 & & & & \\
\hline Republic of Korea & 1 & & & & \\
\hline Singapore & 1 & & & & \\
\hline
\end{tabular}




\begin{tabular}{|ll|}
\hline Sweden & 1 \\
\hline Switzerland & 1 \\
\hline United Kingdom & 1 \\
\hline United States of America & 1 \\
\hline Chile & 1 \\
\hline Croatia & 1 \\
\hline Greece & 1 \\
\hline
\end{tabular}

Source: World Bank Data: Economies by per capita GNI in June 2019

\subsection{Variable description}


Table 3.1

Variable description

\begin{tabular}{|c|c|c|c|}
\hline $\begin{array}{l}\text { Variable } \\
\text { category }\end{array}$ & Pillars & Variables/items & source \\
\hline \multirow{15}{*}{$\begin{array}{l}\text { Independent } \\
\text { variable }\end{array}$} & \multirow[t]{3}{*}{ Institutions } & Political environment & \multirow{15}{*}{$\begin{array}{l}\text { World Intellectual Property } \\
\text { Organization (WIPO): Global } \\
\text { Innovation Index }\end{array}$} \\
\hline & & Regulatory environment & \\
\hline & & Business environment & \\
\hline & \multirow{3}{*}{$\begin{array}{l}\text { Human capital } \\
\text { and research, }\end{array}$} & Education & \\
\hline & & Tertiary education & \\
\hline & & Research and development & \\
\hline & \multirow[t]{3}{*}{ Infrastructure } & $\begin{array}{l}\text { Information and } \\
\text { communication technology } \\
\text { (ICT) }\end{array}$ & \\
\hline & & $\begin{array}{l}\text { General infrastructure that } \\
\text { includes utilities like } \\
\text { electricity }\end{array}$ & \\
\hline & & Ecological sustainability & \\
\hline & \multirow{3}{*}{$\begin{array}{l}\text { Market } \\
\text { sophistication }\end{array}$} & Investment & \\
\hline & & Credit system & \\
\hline & & $\begin{array}{l}\text { Trade, competition, and } \\
\text { market scale }\end{array}$ & \\
\hline & \multirow{3}{*}{$\begin{array}{l}\text { Business } \\
\text { sophistication }\end{array}$} & Knowledge workers & \\
\hline & & Innovation linkage & \\
\hline & & Knowledge absorption & \\
\hline \multirow{6}{*}{$\begin{array}{l}\text { Dependent } \\
\text { Variable }\end{array}$} & \multirow{3}{*}{$\begin{array}{l}\text { Knowledge and } \\
\text { technology } \\
\text { outputs }\end{array}$} & Knowledge creation & \multirow{6}{*}{$\begin{array}{l}\text { World Intellectual Property } \\
\text { Organization (WIPO): Global } \\
\text { Innovation Index }\end{array}$} \\
\hline & & Knowledge impact & \\
\hline & & Knowledge diffusion & \\
\hline & \multirow[t]{3}{*}{$\begin{array}{l}\text { Creative outputs } \\
\text { of innovation }\end{array}$} & $\begin{array}{l}\text { Intangible assets that } \\
\text { include patents and } \\
\text { copyrights }\end{array}$ & \\
\hline & & Creative goods and services & \\
\hline & & Online creativity & \\
\hline \multirow{2}{*}{$\begin{array}{l}\text { Extraneous } \\
\text { Variable }\end{array}$} & \multirow{2}{*}{$\begin{array}{l}\text { Income-level of } \\
\text { countries }\end{array}$} & High-income level & \multirow{2}{*}{$\begin{array}{l}\text { World Bank Data: Economies by per } \\
\text { capita GNI in June } 2019\end{array}$} \\
\hline & & Upper-middle income & \\
\hline
\end{tabular}




\begin{tabular}{|lll|}
\hline $\begin{array}{l}\text { Variable } \\
\text { category }\end{array}$ & Villars & Source \\
\hline & lower-middle income \\
\cline { 2 - 3 } & low income \\
\hline Source: Authors' own creation, 2021 & \\
\hline
\end{tabular}

On contrary to the previous researches (such as Stern et al.,2000; Uku, 2004; Hsu, Tian \& Xu,2014; Qureshi et al.,2020) that only use the size of patent applications to measure innovation performance, this study adopts a diverse set of measures ranging from knowledge creation to knowledge diffusion to gauge innovation performance. The knowledge creation includes patent applications by origin, patent cooperation treaty applications, utility models (petty or short-term patents) by origin, scientific and technical publications, and citable documents $\mathrm{H}$-index. The latter one, knowledge diffusion, incorporates intellectual property receipts, high-tech exports, ICT exports, and foreign direct investment net outflows. The innovation output is also measured in terms of knowledge impact that addresses GDP growth rate of per person employed, new business density, ISO 9001 quality certificates, and high-tech and medium tech manufacturing. Hence, this study not only applies but also overarches the recommendation by Ortega \& Serna (2020), which says the research on innovation performance should not only measure the size of patents but also its impact.

\subsection{Model Specification}

To keep the validity and to reduce the measurement error, the data accuracy has been given prime attention in the selection of the subjects for the analysis. Since the dependent variable is continuous in nature, it allows to apply regression analysis. There is no multicollinearity detected among independent variables. The correlation coefficients in Table 4.2., show that the ' $r$ ' value of all independent variables is less than 0.9. Also, it is proven in the collinearity diagnostics shows variance inflation factor (VIF) is less than 10 and the 'Tolerance' values for all independent variables are greater than 0.1 , which accords with the rule of thumb. Due to less sample size relative to the number of independent variables and the perceived large variation of performance among participating countries, the standardized coefficients and R square adjusted have been given emphasis for interpretation. To reach at robust model with the highest predictive power against the dependent variables, six models were run using the stepwise multiple regression.

\section{Data Presentation And Analysis}

This section is subdivided into four sections: first, the analysis on hypotheses testing results is presented; second, the determinants of knowledge and technology outputs of innovation; next, the determinants of creative outputs of innovation, and analysis of variance (ANOVA) based on Per Capita Income of countries will be presented.

\subsection{Hypotheses testing results}

Below, Table 4.2. shows us the effect of inputs of innovation and their relationship with innovation outputs. The model significantly predicts $86.6 \%$ of innovation outputs. The zero-order or the Pearson correlation coefficients indicate that all the pillar inputs: institutions, human capital and research, infrastructure access, 
and business sophistication have a strong and positive relationship with innovation output with an r-value of 0.7 , except market sophistication $(r=0.662)$. However, we should examine partial and part correlation to control the effect of other independent variables and single out the relationship between each independent variable and innovation variable. In this regard, all pillars, except business sophistication, show a weak correlation with innovation outputs with an $r$ value less than 0.3 as a cut-off point. Also, the unique contribution or effect of all the pillars are insignificant, except business sophistication $(p=0.000, B=0.671)$. Based on this result, our hypothesis test goes as follows:

Table 4.1

Hypothesis testing result

Hypotheses Decision

H1. There is a statistically significant effect and positive Rejected relationship between institutions and innovativeness

H2. There is a statistically significant effect and positive relationship between human capital and innovativeness

Partially accepted, positive correlation but not a significant effect

H3. There is a statistically significant relationship between infrastructure and innovativeness

Partially accepted, positive correlation but not a significant effect

$\mathrm{H} 4$. There is a statistically significant effect and positive relationship between market sophistication and innovativeness

Partially accepted, positive correlation but not a significant effect

H5. There is a statistically significant effect and positive relationship between business sophistication and innovativeness

Accepted

Source: Authors Own estimates, 2021

Business sophistication positively correlates and substantially explains about $76.7 \%$ of innovation outputs and it is the only significant pillar here. It means that a unit change in business sophistication increases a country's innovation outputs by $76.7 \%$. Except for institutions, all others have a positive effect on innovation. In $\mathrm{H} 1$, the institution has no unique significant effect on innovation outputs. As the variables incorporated in each of these pillars are diverse, the item or variable level analysis is needed, which is conducted in the following section. In the like manner, to better understand the partial acceptance of $\mathrm{H} 2, \mathrm{H} 3$, and $\mathrm{H} 4$, the variable-level analysis is needed. Also, this result might have been influenced by the performance and the countries income level, therefore, further analysis on this will figure out in the following section.

Table 4.2. Regression Coefficients ${ }^{a}$ pillar inputs of innovation and innovation outputs 


\begin{tabular}{|c|c|c|c|c|c|c|c|c|c|}
\hline \multicolumn{2}{|c|}{ Model } & \multicolumn{2}{|c|}{$\begin{array}{l}\text { Unstandardized } \\
\text { Coefficients }\end{array}$} & \multirow{2}{*}{$\begin{array}{l}\text { Standardized } \\
\text { Coefficients } \\
\text { Beta }\end{array}$} & \multirow[t]{2}{*}{$\mathrm{T}$} & \multirow[t]{2}{*}{ Sig. } & \multicolumn{3}{|c|}{ Correlations } \\
\hline & & B & $\begin{array}{l}\text { Std. } \\
\text { Error }\end{array}$ & & & & $\begin{array}{l}\text { Zero- } \\
\text { order }\end{array}$ & Partial & Part \\
\hline \multirow[t]{6}{*}{1} & (Constant) & -5.878 & 4.339 & & -1.355 & .181 & & & \\
\hline & Institutions & -.029 & .110 & -.033 & -.263 & .793 & .792 & -.035 & -.013 \\
\hline & $\begin{array}{l}\text { Human capital } \\
\text { and research }\end{array}$ & .015 & .089 & .017 & .169 & .866 & .788 & .022 & .008 \\
\hline & Infrastructure & .238 & .149 & .185 & 1.600 & .115 & .807 & .207 & .078 \\
\hline & $\begin{array}{l}\text { Market } \\
\text { Sophistication }\end{array}$ & .031 & .080 & .030 & .389 & .699 & .662 & .051 & .019 \\
\hline & $\begin{array}{l}\text { Business } \\
\text { Sophistication }\end{array}$ & .671 & .083 & .767 & 8.087 & .000 & .924 & .731 & .393 \\
\hline \multicolumn{10}{|c|}{ a. Dependent Variable: Innovation Output Sub-index } \\
\hline \multicolumn{10}{|c|}{ Source: Own Analysis, 2021} \\
\hline
\end{tabular}

\subsection{Analysis on the determinants of innovation and knowledge and technology outputs}

The determinants of innovation such as political environment, research and development, and knowledge workers, innovation linkages, and knowledge absorption have shown strong and positive correlations ( $r>0.7)$ with knowledge and technology outputs. Whereas tertiary education and ecological sustainability have shown weak correlations of ' $r$ ' value of 0.33 and 0.426 , respectively (Table 3). Model 6 in the model summary, Table 4.3., indicates the best approximate values of prediction on the dependent variable. The model includes all predicting variables (business environment, regulatory environment, political environment, tertiary education, education, research, and development (R\&D), ecological sustainability, general infrastructure, information, and communication technologies (ICTs), investment, trade, competition \& market scale, credit, knowledge absorption, innovation linkages), except knowledge workers. These variables in the model explain about $84 \%$ (adjusted $\left.R^{2}=0.836\right)$ of knowledge and technology outputs with the least value of error (5:5237) and $\left(R^{2}\right.$ change $=0.12, p=0.035$ ). As also shown in the ANOVA Table 4.4., with $p$ value of 0.000 , the model makes statistically significant variance on predicting the dependent variable.

The regression coefficient, Table 4.5. below, shows that knowledge absorption ( $p=0.000$, beta $=.447)$, research and development (R\&D) $(p=0.036$, beta $=0.331)$, and innovation linkages $(p=0.035$, beta $=.260)$ are, consecutively, the highest and statistically significant predictors of knowledge and technology outputs. These variables are also seen with their strong zero-order correlation coefficients and very low 'tolerance' values that all support the unique association and indispensable roles that they play on the knowledge and technology outputs. Both knowledge absorption and innovation linkages refer to the business sophistication pillar and, at 
the pillar level analysis, the same pillar alone explains about $83 \%(b e t a=82.6 \%, p=0.000)$ of knowledge and technology outputs

Table 4.3

Model Summary of Knowledge and Technology Outputs

\begin{tabular}{|c|c|c|c|c|c|c|c|c|c|}
\hline \multirow[t]{2}{*}{ Model } & \multirow[t]{2}{*}{$\mathrm{R}$} & \multirow{2}{*}{$\begin{array}{l}\mathrm{R} \\
\text { Square }\end{array}$} & \multirow{2}{*}{$\begin{array}{l}\text { Adjusted R } \\
\text { Square }\end{array}$} & \multirow{2}{*}{$\begin{array}{l}\text { Std. Error of } \\
\text { the Estimate }\end{array}$} & \multicolumn{5}{|c|}{ Change Statistics } \\
\hline & & & & & $\begin{array}{l}\text { R Square } \\
\text { Change }\end{array}$ & $\begin{array}{l}\mathrm{F} \\
\text { Change }\end{array}$ & df1 & Df2 & Sign. \\
\hline 1 & $.736^{\mathrm{a}}$ & .542 & .519 & 9.4572 & .542 & 23.290 & 3 & 59 & 0.000 \\
\hline 2 & $.848^{b}$ & .719 & .689 & 7.6057 & .177 & 11.740 & 3 & 56 & 0.000 \\
\hline 3 & $.865^{\mathrm{c}}$ & .748 & .705 & 7.4002 & .029 & 2.051 & 3 & 53 & 0.118 \\
\hline 4 & $.871^{d}$ & .759 & .701 & 7.4539 & .011 & .746 & 3 & 50 & 0.530 \\
\hline 5 & $.928^{\mathrm{e}}$ & .860 & .823 & 5.7290 & .101 & 35.640 & 1 & 49 & 0.000 \\
\hline 6 & $.934^{f}$ & .873 & .836 & 5.5237 & .012 & 4.711 & 1 & 48 & 0.035 \\
\hline \multicolumn{10}{|c|}{$\begin{array}{l}\text { f. Predictors: (Constant), Business environment, Regulatory environment, Political environment, Tertiary } \\
\text { Education, Education, R\&D, Ecological sustainability, General infrastructure, (ICTs), Investment, Trade, } \\
\text { Competition \& Marketscale, Credit, Knowledge Absorption, Innovation linkages. }\end{array}$} \\
\hline \multicolumn{10}{|c|}{ g. Dependent Variable: Knowledge \& Technology Outputs } \\
\hline
\end{tabular}

In the first step, when entering variables only from the institution, the political environment is the strongest and statistically significant predictor of knowledge and technology outputs with $p=0.003$ \& beta $=0.603$. In the next step, when coupled with variables from human capital and research, the political environment loses its significant position and R\&D becomes the only strongest \& unique predictor by explaining $69.4 \%(p=0.000$, beta $=0.694$ ) of knowledge and technology outputs. In the third step, further integration with infrastructure variables, the predictive power of $R \& D$ is increased to $78.9 \%$, whereas ecological sustainability explains $23.2 \%$ (beta $=0.232 p=0.018$ ) in a statistically significant way. However, the R square change $(0.029)$ is statistically insignificant with a p-value of 0.118 , as shown in Table 1 . Likewise, the $R^{2}$ change of the fourth model also is insignificant and none of the added market sophistication variables (credit, investment, trade, competition \& market scale) play a statistically significant and unique role in explaining knowledge and technology outputs. In the last sixth model, R\&D, knowledge absorption, and innovation linkages are found to have statistically significant and unique contributions with the highest $R^{2}$ value. Throughout the models tested, $R \& D$ has maintained its statistically significant positions in uniquely predicting the knowledge and technology outputs of innovation (see Table 4.5). 
Table 4.4

ANOVA of Models

\begin{tabular}{|c|c|c|c|c|c|c|}
\hline \multicolumn{7}{|c|}{ ANOVA $^{a}$} \\
\hline \multicolumn{2}{|c|}{ Model } & Sum of Squares & Df & Mean Square & $\mathrm{F}$ & Sig. \\
\hline \multirow[t]{3}{*}{1} & Regression & 6249.082 & 3 & 2083.027 & 23.290 & $.000^{\mathrm{b}}$ \\
\hline & Residual & 5276.872 & 59 & 89.439 & & \\
\hline & Total & 11525.954 & 62 & & & \\
\hline \multirow[t]{3}{*}{2} & Regression & 8286.511 & 6 & 1381.085 & 23.875 & $.000^{c}$ \\
\hline & Residual & 3239.443 & 56 & 57.847 & & \\
\hline & Total & 11525.954 & 62 & & & \\
\hline \multirow[t]{3}{*}{3} & Regression & 8623.534 & 9 & 958.170 & 17.497 & $.000^{d}$ \\
\hline & Residual & 2902.420 & 53 & 54.763 & & \\
\hline & Total & 11525.954 & 62 & & & \\
\hline \multirow[t]{3}{*}{4} & Regression & 8747.928 & 12 & 728.994 & 13.121 & $.000^{\mathrm{e}}$ \\
\hline & Residual & 2778.027 & 50 & 55.561 & & \\
\hline & Total & 11525.954 & 62 & & & \\
\hline \multirow[t]{3}{*}{5} & Regression & 9917.683 & 13 & 762.899 & 23.244 & $.000^{f}$ \\
\hline & Residual & 1608.271 & 49 & 32.822 & & \\
\hline & Total & 11525.954 & 62 & & & \\
\hline \multirow[t]{3}{*}{6} & Regression & 10061.425 & 14 & 718.673 & 23.555 & $.000^{g}$ \\
\hline & Residual & 1464.529 & 48 & 30.511 & & \\
\hline & Total & 11525.954 & 62 & & & \\
\hline \multicolumn{7}{|c|}{ aDependent Variable: Knowledge \& Technology Outputs } \\
\hline \multicolumn{7}{|c|}{$\begin{array}{l}\text { gPredictors: (Constant), Business environment, Regulatory environment, Political environment, Tertiary } \\
\text { Education, Education, R\&D, Ecological sustainability, General infrastructure, ICTs, Investment, Trade, } \\
\text { competition \& market scale, Credit, Knowledge Absorption, Innovation linkages }\end{array}$} \\
\hline
\end{tabular}


Table 4.5

Regression Coefficients of the Predictors of Knowledge and Technology Output

\begin{tabular}{|c|c|c|c|c|c|c|c|c|c|}
\hline \multicolumn{10}{|c|}{ Coefficients ${ }^{a}$} \\
\hline \multicolumn{2}{|c|}{ Model } & \multicolumn{2}{|c|}{$\begin{array}{l}\text { Unstandardized } \\
\text { Coefficients }\end{array}$} & \multirow{2}{*}{$\begin{array}{l}\text { Standardized } \\
\text { Coefficients } \\
\text { Beta }\end{array}$} & \multirow[t]{2}{*}{$\mathrm{T}$} & \multirow[t]{2}{*}{ Sig. } & \multicolumn{3}{|c|}{ Correlations } \\
\hline & & $\mathrm{B}$ & $\begin{array}{l}\text { Std. } \\
\text { Error }\end{array}$ & & & & $\begin{array}{l}\text { Zero- } \\
\text { order }\end{array}$ & Partial & Part \\
\hline \multirow[t]{15}{*}{6} & (Constant) & -18.831 & 11.326 & & -1.663 & .103 & & & \\
\hline & $\begin{array}{l}\text { Political } \\
\text { environment }\end{array}$ & -.188 & .130 & -.233 & -1.453 & .153 & .728 & -.205 & -.075 \\
\hline & $\begin{array}{l}\text { Regulatory } \\
\text { environment }\end{array}$ & .086 & .108 & .101 & .789 & .434 & .633 & .113 & .041 \\
\hline & $\begin{array}{l}\text { Business } \\
\text { environment }\end{array}$ & .117 & .126 & .089 & .928 & .358 & .612 & .133 & .048 \\
\hline & Education & .174 & .112 & .138 & 1.551 & .127 & .514 & .218 & .080 \\
\hline & Tertiary Education & .006 & .068 & .006 & .092 & .927 & .339 & .013 & .005 \\
\hline & $\begin{array}{l}\text { Research and } \\
\text { development(R\&D) }\end{array}$ & .179 & .083 & .331 & 2.155 & .036 & .831 & .297 & .111 \\
\hline & ICTs & -.218 & .148 & -.216 & -1.473 & .147 & .671 & -.208 & -.076 \\
\hline & $\begin{array}{l}\text { General } \\
\text { infrastructure }\end{array}$ & .015 & .110 & .013 & .137 & .892 & .556 & .020 & .007 \\
\hline & $\begin{array}{l}\text { Ecological } \\
\text { sustainability }\end{array}$ & .174 & .093 & .142 & 1.875 & .067 & .426 & .261 & .096 \\
\hline & Credit & .008 & .068 & .011 & .115 & .909 & .573 & .017 & .006 \\
\hline & Investment & .027 & .096 & .024 & .277 & .783 & .574 & .040 & .014 \\
\hline & $\begin{array}{l}\text { Trade, Competition } \\
\& \text { Marketscale }\end{array}$ & .172 & .133 & .122 & 1.295 & .202 & .495 & .184 & .067 \\
\hline & $\begin{array}{l}\text { Knowledge } \\
\text { Absorption }\end{array}$ & .529 & .103 & .447 & 5.114 & .000 & .823 & .594 & .263 \\
\hline & $\begin{array}{l}\text { Innovation } \\
\text { linkages }\end{array}$ & .226 & .104 & .260 & 2.171 & .035 & .791 & .299 & .112 \\
\hline
\end{tabular}

a. dependent variable: knowledge \& technology outputs

\subsection{Analysis on Determinants of Innovation and Creative Outputs}

As shown in the Table 4.8., except trade, competition \& market scale $(r=0.255, p=0.022)$, tertiary education $(r=0.366, p=0.002)$ and general infrastructure $(r=0.453, p=0.000)$, all other independent variables have strong and positive correlation with creative outputs. As it is seen in Table 4.5., tertiary education also has shown a 
weak correlation ( $r=0.33)$ with knowledge and technology outputs. Among the stepwise regression models (see, Table 4 \&5), model 5 gives the best prediction and about $75.3 \%(p=0.000$, sign $F$ Change $=0.003)$ of creative outputs is explained by the political environment, tertiary education, education, R\&D, ecological sustainability, general infrastructure, ICTs, investment, trade, competition \& market scale, credit, and innovation linkages. In this model, regulatory environment \& business environment from a pillar of institution and knowledge workers and knowledge absorption from business sophistication pillar are removed by the system due to the initial stepping method criteria.

Table 4.6

Model summary for Creative Outputs

\begin{tabular}{|c|c|c|c|c|c|c|c|c|c|}
\hline \multicolumn{10}{|c|}{ Model Summary $f$} \\
\hline \multirow[t]{2}{*}{ Model } & \multirow[t]{2}{*}{$\mathrm{R}$} & \multirow{2}{*}{$\begin{array}{l}\mathrm{R} \\
\text { Square }\end{array}$} & \multirow{2}{*}{$\begin{array}{l}\text { Adjusted } \\
\text { R Square }\end{array}$} & \multirow{2}{*}{$\begin{array}{l}\text { Std. Error of } \\
\text { the Estimate }\end{array}$} & \multicolumn{5}{|c|}{ Change Statistics } \\
\hline & & & & & $\begin{array}{l}\text { R Square } \\
\text { Change }\end{array}$ & $\begin{array}{l}\text { F } \\
\text { Change }\end{array}$ & $\mathrm{df} 1$ & $\mathrm{df} 2$ & $\begin{array}{l}\text { signF } \\
\text { change }\end{array}$ \\
\hline 1 & $.829^{a}$ & .688 & .683 & 6.0752 & .688 & 134.538 & 1 & 61 & 0.000 \\
\hline 2 & $.845^{\mathrm{b}}$ & .714 & .695 & 5.9621 & .026 & 1.779 & 3 & 58 & 0.161 \\
\hline 3 & $.868^{c}$ & .754 & .722 & 5.6866 & .039 & 2.918 & 3 & 55 & 0.042 \\
\hline 4 & $.870^{d}$ & .757 & .711 & 5.8043 & .004 & .264 & 3 & 52 & 0.851 \\
\hline 5 & $.893^{\mathrm{e}}$ & .797 & .753 & 5.3640 & .039 & 9.887 & 1 & 51 & 0.003 \\
\hline
\end{tabular}

a. Predictors: (Constant), Political environment

b. Predictors: (Constant), Political environment, Tertiary Education, Education, R\&D

c. Predictors: (Constant), Political environment, Tertiary Education, Education, R\&D, Ecological sustainability, General infrastructure, ICTs

d. Predictors: (Constant), Political environment, Tertiary Education, Education, R\&D, Ecological sustainability, General infrastructure, ICTs, Investment, Trade, Competition \& Marketscale, Credit

e. Predictors: (Constant), Political environment, Tertiary Education, Education, R\&D, Ecological sustainability, General infrastructure, ICTs, Investment, Trade, Competition \& Marketscale, Credit, Innovation linkages

\section{f. Dependent Variable: Creative Outputs}

Likewise, as happened to the knowledge and technology outputs, the political environment is the only predictor among the institution pillar variables that explain creative outputs in a statistically significant way in the first model in the absence of variables from other pillars. However, in both dependent variables' cases, when it is coupled with variables from all other pillars, its unique contribution to creative outputs has become statistically insignificant (beta $=0.249, p=0.129$ ). The two statistically significant predictors of creative outputs are innovation linkages (beta $=0.433, p=0.003$ ) and ecological sustainability (beta $=0.192, p=.038$ ) (see Table 6 , model 5). At a pillar level, creative outputs have strong and positive correlation with infrastructure $(r=0.805$, $p=0.000)$ and business sophistication $(r=0.850, p=0.000)$. All the pillars (institution, human capital and 
research, infrastructure, market sophistication, and business sophistication) collectively explain about 76\% ( $R$ adjusted square $=0.758$, with sign. $F$ change $=0.000$ and ANOVA $p=0.000$ ). But in this model, only business sophistication (beta $=0.608, P=0.000$ ) has a statistically significant effect on creative outputs.

Table 5

, ANOVA for models of Creative Output and its Predictors

\begin{tabular}{|c|c|c|c|c|c|c|}
\hline \multicolumn{7}{|c|}{ ANOVA $^{a}$} \\
\hline \multicolumn{2}{|c|}{ Model } & \multirow{2}{*}{$\begin{array}{l}\text { Sum of Squares } \\
4965.557\end{array}$} & \multirow{2}{*}{$\begin{array}{l}\mathrm{df} \\
1\end{array}$} & \multirow{2}{*}{$\begin{array}{l}\text { Mean Square } \\
4965.557\end{array}$} & \multirow{2}{*}{$\begin{array}{l}F \\
134.538\end{array}$} & \multirow{2}{*}{$\begin{array}{l}\text { Sig. } \\
.000^{t}\end{array}$} \\
\hline 1 & Regression & & & & & \\
\hline & Residual & 2251.407 & 61 & 36.908 & & \\
\hline & Total & 7216.964 & 62 & & & \\
\hline \multirow[t]{3}{*}{2} & Regression & 5155.275 & 4 & 1288.819 & 36.257 & $.000^{c}$ \\
\hline & Residual & 2061.689 & 58 & 35.546 & & \\
\hline & Total & 7216.964 & 62 & & & \\
\hline \multirow[t]{3}{*}{3} & Regression & 5438.401 & 7 & 776.914 & 24.025 & $.000^{\mathrm{d}}$ \\
\hline & Residual & 1778.563 & 55 & 32.338 & & \\
\hline & Total & 7216.964 & 62 & & & \\
\hline \multirow[t]{3}{*}{4} & Regression & 5465.115 & 10 & 546.512 & 16.222 & $.000^{\mathrm{e}}$ \\
\hline & Residual & 1751.849 & 52 & 33.689 & & \\
\hline & Total & 7216.964 & 62 & & & \\
\hline \multirow[t]{3}{*}{5} & Regression & 5749.581 & 11 & 522.689 & 18.166 & $.000^{f}$ \\
\hline & Residual & 1467.383 & 51 & 28.772 & & \\
\hline & Total & 7216.964 & 62 & & & \\
\hline
\end{tabular}

a. Dependent Variable: Creative Outputs

b. Predictors: (Constant), Political environment

c. Predictors: (Constant), Political environment, Tertiary Education, Education, R\&D

d. Predictors: (Constant), Political environment, Tertiary Education, Education, R\&D, Ecological sustainability, General infrastructure, ICTs

e. Predictors: (Constant), Political environment, Tertiary Education, Education, R\&D, Ecological sustainability, General infrastructure, ICTs, Investment, Trade, Competition \& Marketscale, Credit

f. Predictors: (Constant), Political environment, Tertiary Education, Education, R\&D, Ecological sustainability, General infrastructure, ICTs, Investment, Trade, Competition \& Market scale, Credit, Innovation linkages 
Table 4.8

Regression coefficient of predictors of Creative Outputs

\begin{tabular}{|c|c|c|c|c|c|c|c|c|c|}
\hline \multicolumn{10}{|c|}{ Coefficients $^{a}$} \\
\hline \multicolumn{2}{|c|}{ Model } & \multicolumn{2}{|c|}{$\begin{array}{l}\text { Unstandardized } \\
\text { Coefficients }\end{array}$} & \multirow{2}{*}{$\begin{array}{l}\text { Standardized } \\
\text { Coefficients } \\
\text { Beta }\end{array}$} & \multirow[t]{2}{*}{$T$} & \multirow[t]{2}{*}{ Sig. } & \multicolumn{3}{|c|}{ Correlations } \\
\hline & & B & $\begin{array}{l}\text { Std. } \\
\text { Error }\end{array}$ & & & & $\begin{array}{l}\text { Zero- } \\
\text { order }\end{array}$ & Partial & Part \\
\hline \multirow[t]{12}{*}{5} & (Constant) & -14.908 & 10.360 & & -1.439 & .156 & & & \\
\hline & $\begin{array}{l}\text { Political } \\
\text { environment }\end{array}$ & .159 & .120 & .249 & 1.322 & .192 & .829 & .182 & .084 \\
\hline & Education & .166 & .106 & .167 & 1.568 & .123 & .642 & .214 & .099 \\
\hline & $\begin{array}{l}\text { Tertiary } \\
\text { Education }\end{array}$ & -.042 & .065 & -.051 & -.645 & .522 & .366 & -.090 & -.041 \\
\hline & $R \& D$ & -.069 & .079 & -.160 & -.862 & .393 & .685 & -.120 & -.054 \\
\hline & ICTs & .129 & .130 & .161 & .992 & .326 & .740 & .138 & .063 \\
\hline & $\begin{array}{l}\text { General } \\
\text { infrastructure }\end{array}$ & .120 & .100 & .126 & 1.201 & .235 & .453 & .166 & .076 \\
\hline & $\begin{array}{l}\text { Ecological } \\
\text { sustainability }\end{array}$ & .185 & .087 & .192 & 2.130 & .038 & .605 & .286 & .134 \\
\hline & Credit & -.002 & .060 & -.003 & -.028 & .978 & .586 & -.004 & -.002 \\
\hline & Investment & -.032 & .092 & -.036 & -.344 & .732 & .483 & -.048 & -.022 \\
\hline & $\begin{array}{l}\text { Trade, } \\
\text { Competition \& } \\
\text { Market scale }\end{array}$ & .051 & .118 & .046 & .433 & .667 & .255 & .061 & .027 \\
\hline & $\begin{array}{l}\text { Innovation } \\
\text { linkages }\end{array}$ & .298 & .095 & .433 & 3.144 & .003 & .754 & .403 & .199 \\
\hline
\end{tabular}

a. Dependent variable: creative outputs

\subsection{Analysis of Variance (ANOVA) based on Per Capita Income of countries}

The countries included in the study are grouped into four based on World Bank's income-based country classification[1]: high-income (1), upper-middle income (2), lower-middle-income countries (3), and lowincome countries (4). This study emphasizes on the first three categories. To analyze the variance based on economic growth, the pillars of independent pillars are considered: institution, education and research, infrastructure, market sophistication, and business sophistication. The analysis also considers the performance of countries in both innovation outputs: knowledge and technology outputs and creative outputs. Subsequently, further variable or item level analysis is also done to substantiate the variance among countries. 
Levene's test uses an 'F-test' to test the null hypothesis that assumes the variance is equal across groups. A ' $P$ ' value less than .05 indicates a violation of the assumption[2]. In the test of homogeneity of variance, Table 4.10 appendix, innovation input sub-index in general and institutions and business sophistication pillars violate the assumption of F-test and show that the three groups of countries are statistically at a different level of performance. ANOVA result (Table 4.11) is consistent with this and means of innovation performance significantly vary within a group and across groups. Specifically, the post-hoc tests of Tukey HSD (Table 4.12, appendix) show that institutions, access to infrastructure, and human capital and research are significantly different across three groups of countries. The three variables are in the same category under homogeneous subsets Table 4.13.

Table 4.10

Test of Homogeneity of Variance

\begin{tabular}{|c|c|c|c|c|}
\hline \multicolumn{5}{|c|}{ Test of Homogeneity of Variances } \\
\hline & Levene Statistic & df1 & $\mathrm{df} 2$ & Sig. \\
\hline InnovationInputSub-index & 8.836 & 2 & 60 & .000 \\
\hline Innovation Output Sub-index & 1.600 & 2 & 60 & .210 \\
\hline Institutions & 3.286 & 2 & 60 & .044 \\
\hline Human capital and research & 2.731 & 2 & 60 & .073 \\
\hline Infrastructure & 1.272 & 2 & 60 & .288 \\
\hline Market Sophistication & 1.069 & 2 & 60 & .350 \\
\hline Business Sophistication & 5.052 & 2 & 60 & .009 \\
\hline
\end{tabular}


Table 4.11

ANOVA table for Percapita Income and determinants

\begin{tabular}{|c|c|c|c|c|c|c|}
\hline \multicolumn{7}{|l|}{ ANOVA } \\
\hline & & $\begin{array}{l}\text { Sum of } \\
\text { Squares }\end{array}$ & df & $\begin{array}{l}\text { Mean } \\
\text { Square }\end{array}$ & $\mathrm{F}$ & Sig. \\
\hline \multirow[t]{3}{*}{ InnovationInputSub-index } & $\begin{array}{l}\text { Between } \\
\text { Groups }\end{array}$ & 4857.050 & 2 & 2428.525 & 56.302 & .000 \\
\hline & Within Groups & 2588.053 & 60 & 43.134 & & \\
\hline & Total & 7445.103 & 62 & & & \\
\hline \multirow[t]{3}{*}{$\begin{array}{l}\text { Innovation Output Sub- } \\
\text { index }\end{array}$} & $\begin{array}{l}\text { Between } \\
\text { Groups }\end{array}$ & 4184.161 & 2 & 2092.081 & 29.900 & .000 \\
\hline & Within Groups & 4198.103 & 60 & 69.968 & & \\
\hline & Total & 8382.264 & 62 & & & \\
\hline \multirow[t]{3}{*}{ Institutions } & $\begin{array}{l}\text { Between } \\
\text { Groups }\end{array}$ & 8259.462 & 2 & 4129.731 & 89.232 & .000 \\
\hline & Within Groups & 2776.842 & 60 & 46.281 & & \\
\hline & Total & 11036.304 & 62 & & & \\
\hline \multirow[t]{3}{*}{$\begin{array}{l}\text { Human capital and } \\
\text { research }\end{array}$} & $\begin{array}{l}\text { Between } \\
\text { Groups }\end{array}$ & 5897.739 & 2 & 2948.870 & 33.929 & .000 \\
\hline & Within Groups & 5214.854 & 60 & 86.914 & & \\
\hline & Total & 11112.593 & 62 & & & \\
\hline \multirow[t]{3}{*}{ Infrastructure } & $\begin{array}{l}\text { Between } \\
\text { Groups }\end{array}$ & 3411.564 & 2 & 1705.782 & 60.977 & .000 \\
\hline & Within Groups & 1678.444 & 60 & 27.974 & & \\
\hline & Total & 5090.009 & 62 & & & \\
\hline \multirow[t]{3}{*}{ Market Sophistication } & $\begin{array}{l}\text { Between } \\
\text { Groups }\end{array}$ & 2482.809 & 2 & 1241.404 & 13.792 & .000 \\
\hline & Within Groups & 5400.522 & 60 & 90.009 & & \\
\hline & Total & 7883.331 & 62 & & & \\
\hline \multirow[t]{3}{*}{ Business Sophistication } & $\begin{array}{l}\text { Between } \\
\text { Groups }\end{array}$ & 5352.277 & 2 & 2676.138 & 28.729 & .000 \\
\hline & Within Groups & 5589.063 & 60 & 93.151 & & \\
\hline & Total & 10941.339 & 62 & & & \\
\hline
\end{tabular}


Table 4.12

Post Hoc Tests: Multiple Comparisons

\section{Multiple Comparisons}

Tukey HSD

\begin{tabular}{|c|c|c|c|c|c|c|c|}
\hline \multirow[t]{2}{*}{ Dependent Variable } & \multirow{2}{*}{$\begin{array}{l}\text { (I) } \\
\text { Economies } \\
\text { by per } \\
\text { capita GNI } \\
\text { in June } \\
2019 \text { by } \\
\text { World Bank }\end{array}$} & \multirow{2}{*}{$\begin{array}{l}(\mathrm{J}) \\
\text { Economies } \\
\text { by per } \\
\text { capita GNI } \\
\text { in June } \\
2019 \text { by } \\
\text { World Bank }\end{array}$} & \multirow{2}{*}{$\begin{array}{l}\text { Mean } \\
\text { Difference } \\
(I-J)\end{array}$} & \multirow[t]{2}{*}{$\begin{array}{l}\text { Std. } \\
\text { Error }\end{array}$} & \multirow[t]{2}{*}{ Sig. } & \multicolumn{2}{|c|}{$\begin{array}{l}95 \% \text { Confidence } \\
\text { Interval }\end{array}$} \\
\hline & & & & & & $\begin{array}{l}\text { Lower } \\
\text { Bound }\end{array}$ & $\begin{array}{l}\text { Upper } \\
\text { Bound }\end{array}$ \\
\hline \multirow[t]{6}{*}{$\begin{array}{l}\text { InnovationlnputSub- } \\
\text { index }\end{array}$} & \multirow[t]{2}{*}{$\begin{array}{l}\text { High- } \\
\text { income }\end{array}$} & $\begin{array}{l}\text { Upper- } \\
\text { middle- } \\
\text { income }\end{array}$ & $14.1258^{*}$ & 1.9327 & .000 & 9.481 & 18.771 \\
\hline & & $\begin{array}{l}\text { Lower- } \\
\text { middle- } \\
\text { income }\end{array}$ & $21.9511^{*}$ & 2.3477 & .000 & 16.309 & 27.593 \\
\hline & \multirow{2}{*}{$\begin{array}{l}\text { Upper- } \\
\text { middle- } \\
\text { income }\end{array}$} & High-income & $-14.1258^{\star}$ & 1.9327 & .000 & -18.771 & -9.481 \\
\hline & & $\begin{array}{l}\text { Lower- } \\
\text { middle- } \\
\text { income }\end{array}$ & $7.8253^{*}$ & 2.6174 & .011 & 1.535 & 14.115 \\
\hline & \multirow{2}{*}{$\begin{array}{l}\text { Lower- } \\
\text { middle- } \\
\text { income }\end{array}$} & High-income & $-21.9511^{\star}$ & 2.3477 & .000 & -27.593 & -16.309 \\
\hline & & $\begin{array}{l}\text { Upper- } \\
\text { middle- } \\
\text { income }\end{array}$ & $-7.8253^{*}$ & 2.6174 & .011 & -14.115 & -1.535 \\
\hline \multirow[t]{6}{*}{$\begin{array}{l}\text { Innovation Output } \\
\text { Sub-index }\end{array}$} & \multirow[t]{2}{*}{$\begin{array}{l}\text { High- } \\
\text { income }\end{array}$} & $\begin{array}{l}\text { Upper- } \\
\text { middle- } \\
\text { income }\end{array}$ & $15.5819^{*}$ & 2.4616 & .000 & 9.666 & 21.498 \\
\hline & & $\begin{array}{l}\text { Lower- } \\
\text { middle- } \\
\text { income }\end{array}$ & $17.8083^{*}$ & 2.9901 & .000 & 10.623 & 24.994 \\
\hline & \multirow{2}{*}{$\begin{array}{l}\text { Upper- } \\
\text { middle- } \\
\text { income }\end{array}$} & High-income & $-15.5819^{*}$ & 2.4616 & .000 & -21.498 & -9.666 \\
\hline & & $\begin{array}{l}\text { Lower- } \\
\text { middle- } \\
\text { income }\end{array}$ & 2.2265 & 3.3336 & .783 & -5.785 & 10.238 \\
\hline & \multirow{2}{*}{$\begin{array}{l}\text { Lower- } \\
\text { middle- } \\
\text { income }\end{array}$} & High-income & $-17.8083^{*}$ & 2.9901 & .000 & -24.994 & -10.623 \\
\hline & & $\begin{array}{l}\text { Upper- } \\
\text { middle- } \\
\text { income }\end{array}$ & -2.2265 & 3.3336 & .783 & -10.238 & 5.785 \\
\hline Institutions & $\begin{array}{l}\text { High- } \\
\text { income }\end{array}$ & $\begin{array}{l}\text { Upper- } \\
\text { middle- } \\
\text { income }\end{array}$ & $19.4018^{*}$ & 2.0020 & .000 & 14.591 & 24.213 \\
\hline
\end{tabular}




\begin{tabular}{|c|c|c|c|c|c|c|c|}
\hline & & $\begin{array}{l}\text { Lower- } \\
\text { middle- } \\
\text { income }\end{array}$ & $27.7894^{*}$ & 2.4318 & .000 & 21.945 & 33.634 \\
\hline & \multirow{2}{*}{$\begin{array}{l}\text { Upper- } \\
\text { middle- } \\
\text { income }\end{array}$} & High-income & $-19.4018^{\star}$ & 2.0020 & .000 & -24.213 & -14.591 \\
\hline & & $\begin{array}{l}\text { Lower- } \\
\text { middle- } \\
\text { income }\end{array}$ & $8.3876^{*}$ & 2.7112 & .008 & 1.872 & 14.903 \\
\hline & \multirow{2}{*}{$\begin{array}{l}\text { Lower- } \\
\text { middle- } \\
\text { income }\end{array}$} & High-income & $-27.7894^{\star}$ & 2.4318 & .000 & -33.634 & -21.945 \\
\hline & & $\begin{array}{l}\text { Upper- } \\
\text { middle- } \\
\text { income }\end{array}$ & $-8.3876^{*}$ & 2.7112 & .008 & -14.903 & -1.872 \\
\hline \multirow[t]{6}{*}{$\begin{array}{l}\text { Human capital and } \\
\text { research }\end{array}$} & \multirow[t]{2}{*}{$\begin{array}{l}\text { High- } \\
\text { income }\end{array}$} & $\begin{array}{l}\text { Upper- } \\
\text { middle- } \\
\text { income }\end{array}$ & $15.3484^{*}$ & 2.7435 & .000 & 8.755 & 21.942 \\
\hline & & $\begin{array}{l}\text { Lower- } \\
\text { middle- } \\
\text { income }\end{array}$ & $24.3578^{*}$ & 3.3325 & .000 & 16.349 & 32.367 \\
\hline & \multirow{2}{*}{$\begin{array}{l}\text { Upper- } \\
\text { middle- } \\
\text { income }\end{array}$} & High-income & $-15.3484^{*}$ & 2.7435 & .000 & -21.942 & -8.755 \\
\hline & & $\begin{array}{l}\text { Lower- } \\
\text { middle- } \\
\text { income }\end{array}$ & $9.0094^{*}$ & 3.7154 & .048 & .081 & 17.938 \\
\hline & \multirow{2}{*}{$\begin{array}{l}\text { Lower- } \\
\text { middle- } \\
\text { income }\end{array}$} & High-income & $-24.3578^{\star}$ & 3.3325 & .000 & -32.367 & -16.349 \\
\hline & & $\begin{array}{l}\text { Upper- } \\
\text { middle- } \\
\text { income }\end{array}$ & $-9.0094^{*}$ & 3.7154 & .048 & -17.938 & -.081 \\
\hline \multirow[t]{6}{*}{ Infrastructure } & \multirow[t]{2}{*}{$\begin{array}{l}\text { High- } \\
\text { income }\end{array}$} & $\begin{array}{l}\text { Upper- } \\
\text { middle- } \\
\text { income }\end{array}$ & $10.6706^{*}$ & 1.5565 & .000 & 6.930 & 14.411 \\
\hline & & $\begin{array}{l}\text { Lower- } \\
\text { middle- } \\
\text { income }\end{array}$ & $19.2100^{*}$ & 1.8906 & .000 & 14.666 & 23.754 \\
\hline & \multirow{2}{*}{$\begin{array}{l}\text { Upper- } \\
\text { middle- } \\
\text { income }\end{array}$} & High-income & $-10.6706^{*}$ & 1.5565 & .000 & -14.411 & -6.930 \\
\hline & & $\begin{array}{l}\text { Lower- } \\
\text { middle- } \\
\text { income }\end{array}$ & $8.5394^{*}$ & 2.1078 & .000 & 3.474 & 13.605 \\
\hline & \multirow{2}{*}{$\begin{array}{l}\text { Lower- } \\
\text { middle- } \\
\text { income }\end{array}$} & High-income & $-19.2100^{\star}$ & 1.8906 & .000 & -23.754 & -14.666 \\
\hline & & $\begin{array}{l}\text { Upper- } \\
\text { middle- } \\
\text { income }\end{array}$ & $-8.5394^{*}$ & 2.1078 & .000 & -13.605 & -3.474 \\
\hline
\end{tabular}




\begin{tabular}{|c|c|c|c|c|c|c|c|}
\hline \multicolumn{8}{|c|}{ Multiple Comparisons } \\
\hline \multirow[t]{6}{*}{$\begin{array}{l}\text { Market } \\
\text { Sophistication }\end{array}$} & \multirow[t]{2}{*}{$\begin{array}{l}\text { High- } \\
\text { income }\end{array}$} & $\begin{array}{l}\text { Upper- } \\
\text { middle- } \\
\text { income }\end{array}$ & $9.7181^{*}$ & 2.7919 & .003 & 3.009 & 16.428 \\
\hline & & $\begin{array}{l}\text { Lower- } \\
\text { middle- } \\
\text { income }\end{array}$ & $15.9817^{\star}$ & 3.3913 & .000 & 7.832 & 24.132 \\
\hline & \multirow{2}{*}{$\begin{array}{l}\text { Upper- } \\
\text { middle- } \\
\text { income }\end{array}$} & High-income & $-9.7181^{*}$ & 2.7919 & .003 & -16.428 & -3.009 \\
\hline & & $\begin{array}{l}\text { Lower- } \\
\text { middle- } \\
\text { income }\end{array}$ & 6.2635 & 3.7809 & .230 & -2.823 & 15.350 \\
\hline & \multirow{2}{*}{$\begin{array}{l}\text { Lower- } \\
\text { middle- } \\
\text { income }\end{array}$} & High-income & $-15.9817^{*}$ & 3.3913 & .000 & -24.132 & -7.832 \\
\hline & & $\begin{array}{l}\text { Upper- } \\
\text { middle- } \\
\text { income }\end{array}$ & -6.2635 & 3.7809 & .230 & -15.350 & 2.823 \\
\hline \multirow[t]{6}{*}{$\begin{array}{l}\text { Business } \\
\text { Sophistication }\end{array}$} & \multirow[t]{2}{*}{$\begin{array}{l}\text { High- } \\
\text { income }\end{array}$} & $\begin{array}{l}\text { Upper- } \\
\text { middle- } \\
\text { income }\end{array}$ & $15.5219^{*}$ & 2.8402 & .000 & 8.696 & 22.348 \\
\hline & & $\begin{array}{l}\text { Lower- } \\
\text { middle- } \\
\text { income }\end{array}$ & $22.4578^{\star}$ & 3.4500 & .000 & 14.167 & 30.749 \\
\hline & \multirow{2}{*}{$\begin{array}{l}\text { Upper- } \\
\text { middle- } \\
\text { income }\end{array}$} & High-income & $-15.5219^{\star}$ & 2.8402 & .000 & -22.348 & -8.696 \\
\hline & & $\begin{array}{l}\text { Lower- } \\
\text { middle- } \\
\text { income }\end{array}$ & 6.9359 & 3.8464 & .177 & -2.308 & 16.180 \\
\hline & \multirow{2}{*}{$\begin{array}{l}\text { Lower- } \\
\text { middle- } \\
\text { income }\end{array}$} & High-income & $-22.4578^{\star}$ & 3.4500 & .000 & -30.749 & -14.167 \\
\hline & & $\begin{array}{l}\text { Upper- } \\
\text { middle- } \\
\text { income }\end{array}$ & -6.9359 & 3.8464 & .177 & -16.180 & 2.308 \\
\hline
\end{tabular}


Table 4.13

Homogeneous subsets

\section{InnovationInputSub-index}

Tukey HSD ${ }^{a, b}$

Economies by per capita GNI in June 2019 by World Bank

$\mathrm{N}$ Subset for alpha $=0.05$

$\begin{array}{lll}1 & 2 & 3\end{array}$

Lower-middle-income

$10 \quad 38.010$

Upper-middle-income

17

45.835

High-income

36

59.961

Sig.

1.000

1.000

1.000

Means for groups in homogeneous subsets are displayed.

a. Uses Harmonic Mean Sample Size $=16.077$.

b. The group sizes are unequal. The harmonic mean of the group sizes is used. Type I error levels are not guaranteed.

\section{Innovation Output Sub-index}

Tukey HSD ${ }^{\mathrm{a}, \mathrm{b}}$

Economies by per capita GNI in June 2019 by World Bank

$\mathrm{N} \quad$ Subset for alpha $=0.05$

1

2

Lower-middle-income

$10 \quad 24.450$

Upper-middle-income

$17 \quad 26.676$

High-income

36

42.258

Sig.

.732

1.000

Means for groups in homogeneous subsets are displayed.

a. Uses Harmonic Mean Sample Size $=16.077$.

b. The group sizes are unequal. The harmonic mean of the group sizes is used. Type I error levels are not guaranteed. 


\section{Institutions}

Tukey HSD ${ }^{a, b}$

Economies by per capita GNI in June 2019 by World Bank

$\mathrm{N} \quad$ Subset for alpha $=0.05$

$1 \quad 3$

Lower-middle-income

$10 \quad 54.830$

Upper-middle-income

17

63.218

High-income

36

82.619

Sig.

1.000

1.000

1.000

Means for groups in homogeneous subsets are displayed.

a. Uses Harmonic Mean Sample Size $=16.077$.

b. The group sizes are unequal. The harmonic mean of the group sizes is used. Type I error levels are not guaranteed.

\section{Human capital and research}

Tukey HSD ${ }^{\mathrm{a}, \mathrm{b}}$

Economies by per capita GNI in June 2019 by World Bank

$\mathrm{N} \quad$ Subset for alpha $=0.05$

1

2

3

Lower-middle-income

$10 \quad 25.420$

Upper-middle-income

17

34.429

High-income

36

49.778

Sig.

1.000

1.000

1.000

Means for groups in homogeneous subsets are displayed.

a. Uses Harmonic Mean Sample Size $=16.077$.

b. The group sizes are unequal. The harmonic mean of the group sizes is used. Type I error levels are not guaranteed. 


\section{Market Sophistication}

Tukey HSD ${ }^{\mathrm{a}, \mathrm{b}}$

Economies by per capita GNI in June 2019 by World Bank

$\mathrm{N} \quad$ Subset for alpha $=0.05$

1

2

Lower-middle-income

$10 \quad 42.360$

Upper-middle-income

$17 \quad 48.624$

High-income

36

58.342

Sig.

.156

1.000

Means for groups in homogeneous subsets are displayed.

a. Uses Harmonic Mean Sample Size $=16.077$.

b. The group sizes are unequal. The harmonic mean of the group sizes is used. Type I error levels are not guaranteed.

\section{Infrastructure}

Tukey HSD ${ }^{a, b}$

Economies by per capita GNI in June 2019 by World Bank

$\mathrm{N} \quad$ Subset for alpha $=0.05$

1

2

3

Lower-middle-income

$10 \quad 40.090$

Upper-middle-income

17

48.629

High-income

36

59.300

Sig.

$1.000 \quad 1.000$

1.000

Means for groups in homogeneous subsets are displayed.

a. Uses Harmonic Mean Sample Size $=16.077$.

b. The group sizes are unequal. The harmonic mean of the group sizes is used. Type I error levels are not guaranteed. 


\section{Business Sophistication}

Tukey HSD ${ }^{\mathrm{a}, \mathrm{b}}$

Economies by per capita GNI in June 2019 by World Bank

$\mathrm{N} \quad$ Subset for alpha $=0.05$

1

2

Lower-middle-income

$10 \quad 27.370$

Upper-middle-income

$17 \quad 34.306$

High-income

36

49.828

Sig.

.112

1.000

Means for groups in homogeneous subsets are displayed.

a. Uses Harmonic Mean Sample Size $=16.077$.

b. The group sizes are unequal. The harmonic mean of the group sizes is used. Type I error levels are not guaranteed.

In a one-to-one comparison, the tests show that there is no significant difference between upper-middle and high-income countries in terms of innovation output index in general and market sophistication and business sophistication innovation input performance. On the other side, the performance of these innovation inputs does not statistically significantly differ between upper-middle-income and lower-middle-income.

Table 4.9

Hypotheses test results

\section{No. Hypothesis}

Decision

H6a: There is a statistically significant variation in determinants of innovation among countries with different income levels.

Accepted

$\begin{array}{ll}\text { H6b: There is a statistically significant variation of determinants of innovation between } & \text { Partially } \\ \text { lower-middle-income and upper-middle-income countries. } & \text { Accepted }\end{array}$

$\begin{array}{ll}\text { H6b: There is a statistically significant variation of determinants of innovation between } & \text { Partially } \\ & \text { lower-middle-income and upper-middle-income countries. }\end{array}$

$\begin{array}{ll}\text { H6b: There is a statistically significant variation of determinants of innovation between } & \text { Partially } \\ & \text { lower-middle-income and upper-middle-income countries. }\end{array}$

H6c: There is a statistically significant variation of determinants of innovation between Accepted upper-middle-income and high-income countries.

Source: own study result, 2021

H6a, clearly shows that the determinants of innovation that affect the innovation outputs in a high-income country may not work for an upper-middle-income or a lower-middle-income country, and vice versa. In H6b, we partially accept this hypothesis because some of the determinants of innovation such as business sophistication and market sophistication do not show a remarkable difference between lower-middle and upper-middle-income countries. On the other side, we see the intensity and importance of determinants of innovation such as institutions, infrastructure, and human capital and research significantly differ between these groups. 
We accept H6c hypothesis because, as shown in ANOVA Table 4.11 and post-hoc tests, Table 4.11(appendix), there is a statistically significant difference between upper-middle-income countries and high-income countries in the performance of all the variables: institutions, infrastructure, human capital, and research and market sophistication and business sophistication. It is to means that a determinant of innovation in uppermiddle-income countries may not exist at all or may not affect the innovation performance in high-income countries with the same intensity.

[1] Source: World Bank, Country classification by income

(https://datahelpdesk.worldbank.org/knowledgebase/articles/906519).

[2] Statistics Solutions. (2013). The Assumption of Homogeneity of Variance - Statistics Solutions. [online] Available at: https://www.statisticssolutions.com/the-assumption-of-homogeneity-of-variance/ [Accessed 15 Jul. 2021].

\section{Discussion}

In general, business sophistication positively correlates and substantially explains (67\%) innovation outputs. It is the only statistically significant pillar and explains about $83 \%$ of knowledge and technology outputs and $60.8 \%$ of creative outputs of innovation. Knowledge absorption and innovation linkages are the business sophistication variables that significantly contribute to knowledge and technology outputs. A free flow of knowledge among the employees, stakeholders and other institutions are crucial to generate new ideas, products, or services. Price et al., (2013) points out a significant relationship between knowledge and innovation of firms. Especially, the innovation linkages among government, research institutions, and customers have been termed as the most significant linkages that boost innovativeness (Hadhri et al., 2016). In line with this, the level of interaction with different parties, especially with academic partners, is the key determinant to boost innovation performance of the developing country (Hadhri et al., 2016; Ortega \& Serna, 2020; Qureshi et al., 2021). An industry perspective study by Giones (2019) unfolds that university-industry collaborations can be enhanced by training that focus on attitude change of firm owners, innovation vouchers and grants by a university.

Among pillars, human capital and research, and business sophistication are the decisive pillars in predicting knowledge and technology outputs. As shown by stepwise regression, a proper set of the business environment, regulatory environment, political environment, tertiary education, education, research, and development (R\&D), ecological sustainability, general infrastructure, information, and communication technologies (ICTs), investment, trade, competition \& market scale, credit, knowledge absorption, and innovation linkages is the best model to predict and enhance knowledge and technology outputs of innovation. The ample of previous studies also support this model; for instance, the credit system (Giang et al., 2019), access to finance (Osano \& Languitone, 2015 and Fernandez, 2017), educational knowledge and skills of human resource (Farsi \& Toghraee,2015; Uvarova \& Vitola, 2019; You et al., 2021) play an important role in the innovativeness of firms. Also, partnership and technology transfer, and R\&D activities (Hadhri et al., 2016; Qureshi et al., 2021), the pace of technological development, and population educational level (GregoPlaner \& Kus, 2020) accelerate innovation Besides, weak institutions deteriorates the confidence of the investors, customers, and industries (Jovovic et al., 2017; Szalacha-Jarmużek \& Pietrowicz, 2018). Technological infrastructure that includes mobile phones, internet access, online platforms, and digital 
workshops are believed to have a tremendous effect on innovativeness of, especially, SMEs in all business areas (ITC, 2018; Oyedele et al., 2014). In a regulatory environment, maintaining institutions like property rights significantly encourages firms to engage more in new products innovation in developing countries (Udimal et al., 2019).

Among these factors, the study further reveals that knowledge absorption, research and development, and innovation linkages, respectively, are the highest and statistically significant predictors of knowledge and technology outputs of innovation. In accord with this, several researchers prove that R\&D and researchers are essential ingredients to enable and increase innovation performance (Hadhri et al., 2016; Farsi \& Toghraee 2015; Qureshi et al., 2021; Uku, 2004). Hadhri, Arvanitis, M'Henni (2016) pinpointed a very strong relationship between R\&D activities and innovation. They further explained that firms those spend more on R \&D activities, innovate more in service, product, and process. In the study covering several countries from Asia-Pacific region and Latin America and the Caribbean, Qureshi et al., (2021) find R\&D, human capital, and infrastructure access, among others, as the key determinants of innovation.

As happened to knowledge and technology outputs, innovation linkage is the main variable under business sophistication contributing to creative outputs of innovation. At pillar level, business sophistication and access to infrastructure are found to be the two key and statistically significant pillars to enhance creative outputs of innovation. Especially, infrastructure that ensures ecological sustainability is the most demanded and, therefore, it shows that utilities including energy alternatives or electricity, machinery, or transportation are needed to be eco-friendly. Also, the result pinpoints that, since almost all the variables are the same, the model that best predicts knowledge and technology outputs can also be applied to explain creative outputs. Hence, to accelerate innovation (including both knowledge and technology outputs and creative outputs), the desired effort need to be appropriated to all these factors (business environment, regulatory environment, political environment, tertiary education, education, R\&D, ecological sustainability, general infrastructure, ICTs, investment, trade, competition \& market scale, credit, knowledge absorption, and innovation linkages). Especially, the results imply that innovation linkages, knowledge absorption, infrastructure, and research and development exert preponderant influence on the innovation performance and may need to draw the utmost priority, including extra budget allocation. This supplements the argument made by Hadhri et al. (2016), Protogerou et al., (2017) and Ortega \& Serna (2020) where they argue that technology collaborations \& networking with universities, interconnection with government, research institutions and customers are the most significant linkages to boost innovation.

However, as shown by hypothesis $(\mathrm{H} 6 \mathrm{a})$ testing result, the determinants of innovation that are in a highincome country does not equally work for an upper-middle-income or a lower-middle-income country, and vice versa. Even if the determinants are the same in all groups, the level of priority and importance in predicting innovation performance is not the same. Further analysis, histogram illustration below, reveals the difference in the performance status of the groups and the bottleneck/s of each group, where poor performance is observed.

\section{Table 5.1. Innovation activities as per countries' income level}




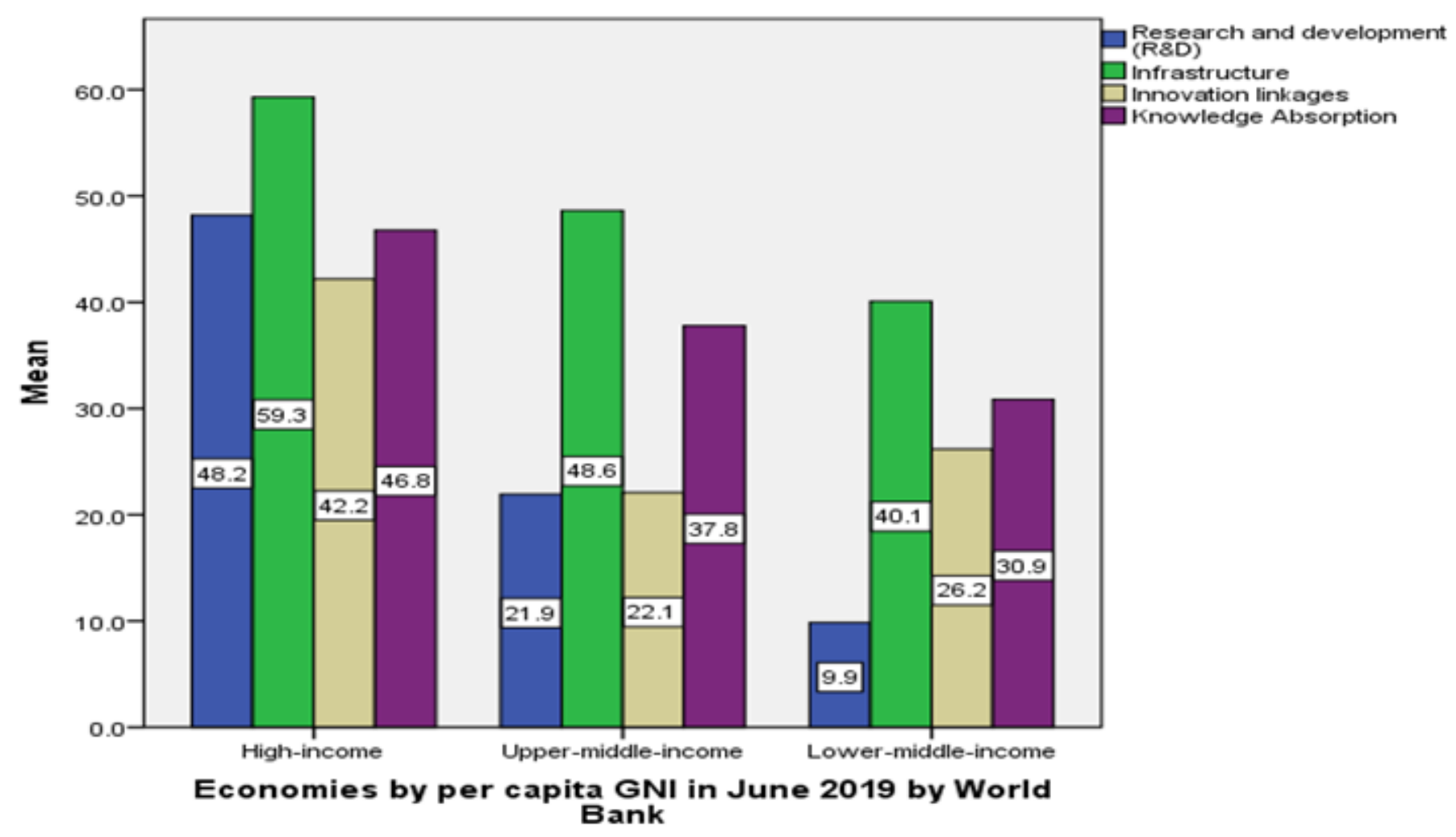

\section{Source: Own study result, 2021}

Therefore, the lower-middle-income countries are expected to give priority to human capital and research (especially focus on R\&D activities), business sophistication (especially focus on innovation linkages followed by knowledge absorption), and infrastructure, respectively. Studies conducted in lower-middleincome countries such as Iran (Farsi \& Toghraee, 2015), Asian countries including India, Vietnam, Bangladesh, and Sri Lanka (Qurashi, Park, Crespi, \& Benavente, 2021) and Nigeria (Agwu, 2014) prove that human capital that promotes R\&D and infrastructure is found to be the key to flourish the innovation. The upper-middle income countries are expected to equally consider both bottlenecks-R\&D and innovation linkage, then pursue knowledge absorption and infrastructure, respectively. It also shows that innovation linkage is a bottleneck, where the high-income countries lag. Therefore, the countries and firms in a high-income category needs to prioritize innovation linkage, knowledge absorption, R\&D, and infrastructure, respectively, to boost their innovation performance, respectively.

\section{Conclusion}

The data for this study were collected from World Intellectual Property Organization (WIPO) and the World Bank country classification website. A total of 63 (48\% of 131) countries were purposefully selected from Global Innovation Index (GII) participating countries with an aim to minimize errors related to measurement and data validity by incorporating countries with full data or missing a very little. Multistage analyses were conducted in which the underlying hypotheses on the determinants of innovation are tested. First, linear regression was conducted on pillars of innovation inputs to identify the most predicting pillars; a stepwise regression was conducted to identify the best predicting model of innovation performance based on variables; the one-way ANOVA analysis was made to examine the level of effect and importance the selected 
determinants in the countries at different income level. The three most important pillars for innovation are business sophistication, human capital and research, and infrastructure. Business sophistication pillar contributes the most in both knowledge and technology outputs and creative outputs dimension of innovation. Especially, knowledge absorption and innovation linkages variables significantly contribute to innovation in general. The other most important variables are research and development (R\&D) and infrastructure that focuses on or includes ecological sustainability.

The best predicting model of determinants of innovation performance should consider the business environment, political environment, tertiary education \& education, research and development (R\&D), ecological sustainability, general infrastructure, information, and communication technologies (ICTs), investment, credit system, knowledge absorption, innovation linkages and trade, competition \& market scale. Among these, the most decisive factors are R\&D activities, innovation linkages, knowledge absorption, and infrastructure. Their level of effect and significance to innovation vary based on countries' income level and countries should give priority to the bottleneck determinants in which they poorly perform or lag. Hence, the high-income countries need to focus on innovation linkage, knowledge absorption, human capital that promotes R\&D, and infrastructure, respectively. Whereas firms and countries in upper-middle-income category can equally prioritize \& invest in human capital that promotes R\&D and innovation linkage, then knowledge absorption comes followed by infrastructure. The lower-middle-income category has to give priority to human capital that promotes R\&D activities, since it is the biggest bottleneck followed by innovation linkages, knowledge absorption and infrastructure, respectively.

\section{Implications And Limitations}

The study results have a multifaceted benefit to various stakeholders including policymakers, financial agents, venture capitalists, donors, business incubators, researchers, and governments, who involve in fostering innovation efforts within a country or across countries. The study result implies that innovation performance is one of the main factors to explain the variation of economic growth of countries which is measured by per-capita income. Besides, the key factors should be identified and prioritized in each category of countries based on the importance of lagging variables. Countries and firms in the lower-middle-income category should not directly imitate what all upper-middle or high-income countries do regarding innovation. They should first work on human capital that promotes R\&D activities, and an adequate budget should also be allocated to it. Without reliable R\&D activities, the problems of innovation cannot easily be defined; if the problems are not identified well, an attempt to bring innovative solutions may not bring the desired results. Following this, the firms \& countries belong to this category can work on innovation linkage. Innovation linkage can be any public/private/academic partnership that bolster innovation in creating a joint venture or deals or sharing innovative resources, knowledge, skills, and experience within a country or abroad. It also includes developing clusters (geographic concentration of firms, suppliers, or producers of related products), patent families filed in two offices, and university/industry research collaboration (Global Innovation Index, 2020). The university-industry collaborative innovation linkage can be enhanced by training that focus on attitude change of businesses, innovation vouchers and grants by a university (Giones, 2019). Then, the countries can work on knowledge absorption and infrastructure. 
Knowledge absorption refers to an organizational capability to integrate, transfer and utilize new knowledge obtained from external sources. Innovation linkage can be a means for knowledge absorption. There is a possibility for knowledge to flow in and out via the linkage created with different partners including institutions, customers, suppliers, competitors, and dealers. Thus, it needs a proper strategy for firms to absorb this knowledge \& then commercialize it. Finally, to commercialize this knowledge, access to infrastructure (both physical and digital infrastructure) is vital and the proper action should be taken to improve the infrastructure in each business unit or sector.

Countries and firms in an upper-middle-income category, can give equal attention to R\&D and innovation linkage at a time, then go for knowledge absorption followed by infrastructure. Whereas countries and firms in a high-income category need to focus on innovation linkage, knowledge absorption, R\&D, and infrastructure, respectively, to further advance their innovation performance. This implies that infrastructure access is not the main bottleneck to all countries and firms, especially, in upper-middle income and high-income categories. As a limitation, the study considers innovation inputs and innovation outputs at a country-level in general; it does not distinguish the innovation performance between large and SMEs. Further research can be done on how these determinants of innovation separately affect SMEs and large businesses that are found in four categories of countries: high-income, upper-middle-income, lower-middle-income, and low-income category.

\section{Declarations}

\section{Availability of data and materials}

The dataset of the study can be accessed from the public website of world intellectual property organization, Global Innovation Index2020: https://www.wipo.int/global_innovation_index/en/

\section{Competing interests}

The authors declare that they have no competing interests

\section{Funding}

This study has not received any sort of research financial support from neither individuals nor institutions. Its APC is covered by the University of Pecs, which is the affiliated institution of the authors.

\section{Authors' contributions}

The literature review including introduction of the study was contributed by Esther Wanjiru Wachira, and all other remaining parts were contributed and articulated by Adisu Fanta Bate, the corresponding author. Technical support and advisory role including proof reading was made by Dr. Sándor Danka.

\section{Acknowledgements}

We would like to express our appreciation to Prof. Luke Pittaway, from Ohio University, for his constructive comments and proof reading of the article. 


\section{References}

1. Agwu, M. O. (2014). Issues, Challengesand Prospectsof Small and Medium Scale Enterprises (SMEs) in Port-Harcourt City,. European Journal of Sustainable Development, 3(1), 101-114. https://doi.org/10.14207/ejsd.2014.v3n1p101

2. Babuchowska, K., \& Marks-Bielska, R. (2021). Determinants of Innovation in Diary Farms in Poland. European Research Studies Journal, XXIV(Issue 1), 1240-1249. https://doi.org/10.35808/ersj/2021

3. Barrichello, A., Paulo, S., Política, E. P. De, Negócios, E., \& Morano, R. S. (2020). Determinant and priority factors of innovation for the development of nations. 17(3), 307-320. https://doi.org/10.1108/INMR-042019-0040

4. Berman, S. (2013). Ideational theorizing in the social sciences since 'Policy paradigms, social learning and the state'. Governance, 26(2), 217-237

5. Bhattacharya, M., \& Bloch, H. (2004). Determinants of innovation. Small Business Economics, 22(2), 155-162. https://doi.org/10.1023/B:SBEJ.0000014453.94445.de

6. Chun-Yao, T. (2014) Technological innovation capability, knowledge sourcing and collaborative innovation in Gulf Cooperation Council countries, Innovation, 16:2, 212-223, DOI:

10.1080/14479338.2014.11081983

7. Damanpour, F. \& Wischnevsky, J. (2006). Research on Innovation in Organizations: Distinguishing Innovation-Generating from Innovation-Adopting Organizations. Journal of Engineering and Technology Management. 23. 269-291. 10.1016/j.jengtecman.2006.08.002.

8. Dima, A. M., Begu, L., Vasilescu, M. D., \& Maassen, M. A. (2018). The relationship between the knowledge economy and global competitiveness in the European Union. Sustainability (Switzerland), 10(6). https://doi.org/10.3390/su10061706

9. Farace, S., \& Mazzotta, F. (2015). The Effect Of Human Capital And Networks On The Effect Of Human Capital And Networks On Knowledge And Innovation. https://doi.org/10.3917/jie.016.0039

10. Farsi, J. Y., \& Toghraee, M. T. (2015a). Erratum to: Identification of the main challenges of small and medium-sized enterprises in exploiting innovative opportunities (Case study: Iran SMEs). Journal of Global Entrepreneurship Research, 5(1). https://doi.org/10.1186/s40497-015-0030-y

11. Fernandez, V. (2017). The finance of innovation in Latin America. Journal of International Review of Financial Analysis, 53, 37-47

12. Frambach, R.T (1993), "An Integrated Model of Organizational Adoption and Diffusion of Innovations", European Journal of Marketing, Vol. 27 No. 5, pp. 22-41. https://doi.org/10.1108/03090569310039705

13. Gachara, H. N. (2017). Innovation Challenges Encountered By Small and Medium Enterprises in Nairobi, Kenya. International Journal of Economics, Commerce and Management, VI(6), 717-738.

14. Giang, M. H., Trung, B. H., Yoshida, Y., Xuan, T. D., \& Que, M. T. (2019). The causal effect of access to finance on the productivity of small and medium enterprises in Vietnam. Sustainability (Switzerland), 11(19), 1-19. https://doi.org/10.3390/su11195451

15. Giones, F. (2019). University-industry collaborations: an industry perspective. Management Decision, 57(12), 3258-3279. https://doi.org/10.1108/md-11-2018-1182 
16. Global Innovation Index (GII)(2020). Global Innovation Index: Resources, retrieved from Wipo.int. https://www.wipo.int/global_innovation_index/en/ on October 01, 2020

17. Grego-Planer, D., \& Kus, A. (2020). Determinants of Innovation Activities in Small Enterprises: A Model Approach. European Research Studies Journal, XXII/(Special Issue 1), 137-148. https://doi.org/10.35808/ersj/1750

18. Hadhri, W., Arvanitis, R., \& M'Henni, H. (2016). Determinants of innovation activities in small and open economies: the Lebanese business sector. Journal of Innovation Economics, 21(3), 77. https://doi.org/10.3917/jie.021.0077

19. Hassan, N., \& Raziq, A. (2019). Effects of knowledge management practices on innovation in SMEs. Management Science Letters, 9(7), 997-1008. https://doi.org/10.5267/j.msl.2019.4.005

20. Hausman, A. (2005). Innovativeness among small businesses: Theory and propositions for future research. Industrial Marketing Management, 34(8), 773-782.

https://doi.org/10.1016/j.indmarman.2004.12.009

21. Hult, G. T. M., Hurley, R. F., \& Knight, G. A. (2004). Innovativeness: Its antecedents and impact on business performance. Industrial Marketing Management, 33(5), 429-438.

https://doi.org/10.1016/j.indmarman.2003.08.015

22. Hsu, Po-Hsuan, Xuan, T., and Yan, X.(2014). Financial development and innovation: Cross-country evidence.Journal of Financial Economics 112, no. 1 (2014): pp. 116-135.

23. Im, S., \& Workman, J. P. (2004). Market Orientation, Creativity, and New Product Performance in HighTechnology Firms. Journal of Marketing, 68(2), 114-132. https://doi.org/10.1509/jmkg.68.2.114.27788

24. ITC. (2018). Promoting SME Competitiveness in Africa: Data for de-risking investment.

25. Jabbouri, N. I., Siron, R., Zahari, I., \& Khalid, M. (2016). Impact of Information Technology Infrastructure on Innovation Performance: An Empirical Study on Private Universities In Iraq. Procedia Economics and Finance, 39(November 2015), 861-869. https://doi.org/10.1016/s2212-5671(16)30250-7

26. Jovovic, R., Draskovic, M., Delibasic, M., \& Jovovic, M. (2017). The concept of sustainable regional development - institutional aspects, policies, and prospects. Journal of International Studies, 10(1), 255-266. https://doi.org/10.14254/2071-8330.2017/10-1/18

27. Kireyeva, A., Nurbatsin, A., Yessentay, A., Bagayeva, N., \& Sharbanu, T. (2021). Exploring determinants of innovation potential of enterprises in Kazakhstan. Problems and Perspectives in Management, 19(2). https://doi.org/10.21511/ppm.19(2).2021.34

28. Kirikkaleli, D., \& Ozun, A. (2019). Innovation capacity, business sophistication, and macroeconomic stability: Empirical evidence from oecd countries. Journal of Business Economics and Management, 20(2), 351-367. https://doi.org/10.3846/jbem.2019.9602

29. Minto-Coy, I. and M. M. (2016). Barriers to Entrepreneurship and Innovation : An Institutional Analysis of Mobile Banking in Jamaica and Kenya Author ( s ): Indianna Minto-Coy and Maurice McNaughton Source : Social and Economic Studies, June / September 2016, Vol. 65, No. 2 / 3 Pub. 65(2), 99-131.

30. Mustafa, H. K., \& Yaakub, S. (2018). Innovation And Technology Adoption Challenges : Impact On SMEs ' Company. International Journal of Accounting, Finance and Business, 3(15), 57-65. 
31. Ndesaulwa, A. P., \& Kikula, J. (2016). The Impact of Innovation on Performance of Small and Medium Enterprises ( SMEs ) in Tanzania : A Review of Empirical Evidence. Journal of Business and Management Sciences, 4(1), 1-6. https://doi.org/10.12691/jbms-4-1-1

32. Nyarku, K. M., \& Oduro, S. (2018). Effect of legal and regulatory framework on SMEs growth in the Accra Metropolis of Ghana. International Journal of Entrepreneurship and Innovation, 19(3), 207-217. https://doi.org/10.1177/1465750317742842

33. Obunike, C. F., \& Udu, A. A. (2019). Technological Innovativeness And Growth : A Study Of Small Scale Manufacturing Рост : Economics of Development, 39-53. https://doi.org/10.21511/ed.17(4).2018.05

34. Okrah, J., \& Hajduk-Stelmachowicz, M. (2020). Political stability and innovation in Africa. Journal of International Studies, 13(1), 234-246. https://doi.org/10.14254/2071-8330.2020/13-1/15

35. Oluwatobi, S., Ola-david, O., Olurinola, I., Alege, P., \& Ogundipe, A. (2016). Human Capital, Institutions and Innovation in Sub-Saharan Africa. 6(4), 1507-1514.

36. Ortega, A. M., \& Serna, M. (2020). Determinants of innovation performance of organizations in a regional innovation system from a developing country. International Journal of Innovation Science, 12(3), 345362. https://doi.org/10.1108/IJIS-03-2020-0023

37. Osano, H. M., \& Languitone, H. (2015). Factors influencing access to finance by SMEs in Mozambique: case of SMEs in Maputo central business district. Journal of Innovation and Entrepreneurship, 5(1). https://doi.org/10.1186/s13731-016-0041-0

38. Oyedele, J., Mcgreal, S., \& Adair, A., \& Ogedengbe, P. (2013). Performance and role of European listed infrastructure in a mixed-asset portfolio. Journal of Financial Management of Property and Construction. 18. 10.1108/JFMPC-07-2012-0022.

39. Oyedele, M., Kabuoh, M., Oduyoye, O., Olalekan, A., \& Elemo, G. (2014). On Entrepreneurial Success of Small and Medium Enterprises (SMEs ): A Conceptual and Theoretical Framework. 5(16), 14-24.

40. Pallent, J. (2007) SPSS Survival Manual: Step by Step guide to Data Analysis Using SPSS version 15 (3rd ed), McGrew Hill, USA

41. Pan, X., Guo, S., Li, M., \& Song, J. (2021). The effect of technology infrastructure investment on technological innovation --A study based on spatial durbin model. Technovation, 107(April), 102315. https://doi.org/10.1016/j.technovation.2021.102315

42. Pisano, G. P. (2015) You Need an Innovation Strategy. Harvard Business Review. pp 44-54

43. Pertuz, V. P., Perez, A. B., \& Geizzelez, M. L. (2018). Determinants of innovation capacity in medium-sized firms. Journal of Physics: Conference Series, 1126(1). https://doi.org/10.1088/17426596/1126/1/012060

44. Price, D. P., Stoica, M., \& Boncella, R. J. (2013). The relationship between innovation, knowledge, and performance in family and non-family firms: an analysis of SMEs. Journal of Innovation and Entrepreneurship, 2(1), 14. https://doi.org/10.1186/2192-5372-2-14

45. Protogerou, A., Caloghirou, Y., \& Vonortas, N. S. (2017). Determinants of young fi rms ' innovative performance : Empirical evidence from Europe. Research Policy, 46(7), 1312-1326.

https://doi.org/10.1016/j.respol.2017.05.011 
46. Qureshi, I., Park, D., Atilio, G., \& Miguel, J. (2021). Trends and determinants of innovation in Asia and the Pacific vs. Latin America and the Caribbean $\otimes$. Journal of Policy Modeling.

https://doi.org/10.1016/j.jpolmod.2020.06.008

47. Razavi, S. M., Abdollahi, B., Ghasemi, R., \& Shafie, H. (2012). Relationship between "Innovation" and "Business Sophistication”: A Secondary Analysis of Countries Global Competitiveness. European Journal of Scientific Research, 79(1), 29-39.

48. Restrepo-Morales, J. A., Loaiza, O. L., \& Vanegas, J. G. (2019). Determinants of innovation: A multivariate analysis in Colombian micro, small and medium-sized enterprises. Journal of Economics, Finance and Administrative Science, 24(47), 97-112. https://doi.org/10.1108/JEFAS-09-2018-0095

49. Sembiring, R. (2016). Impact of Human Resources' Knowledge and Skills on SMEs' in Medan City, Indonesia.

50. Sharif, I., Ali, S., Hussain, S., Khalid, M., Imran, A., \& Nazar, R. (2021). Dynamic common correlated effects of technological innovations and institutional performance on environmental quality : Evidence from East-Asia and Pacific countries. Environmental Science and Policy, 124(May), 313-323. https://doi.org/10.1016/j.envsci.2021.07.007

51. Stanisławski, R., \& Olczak, A. (2010). Innovative activity in the small business sector of the textile and clothing industry. Fibres and Textiles in Eastern Europe, 78(1), 13-16.

52. Stern, S.,Porter, M., and Furman, J. (2000). The Determinants of National Innovative Capacity.NBER Working Paper No. 7876, September. \{City\}: The National Bureau of Economic Research.

53. Szalacha-Jarmużek, J., \& Pietrowicz, K. (2018). Missing causality and absent institutionalization. A case of Poland and methodological challenges for future studies of interlocking directorates. Economics and Sociology, 11(4), 157-172. https://doi.org/10.14254/2071-789X.2018/11-4/10

54. Sudolska, A. and Łapińska, J. (2020). Exploring Determinants of Innovation Capability in Manufacturing Companies Operating in Poland. Sustainability, 12(17), p.7101.

55. Tsatsenko, N., Change, S., \& Growth, E. (2020). Sme Development, Economic Growth And Structural Change : Sme Development, Economic Growth And Structural Change : July. https://doi.org/10.23649/jae.2020.2.14.7

56. Tsetim, J. T., Adegbe, O. B., \& Agema, R. J. (2020). Knowledge Management Infrastructure Capabilities and Innovativeness of Small and Medium Scale Enterprises in Benue State, Nigeria. 6663, 216-225. https://doi.org/10.36348/sjbms.2020.v05i03.006

57. Udimal, T. B., Jincai, Z., Ibn Musah, A.-A., \& Hua, C. (2019). Determinants of new products innovation in Ghanaian SMEs sector. Journal of Global Entrepreneurship Research, 9(1). https://doi.org/10.1186/s40497-018-0124-4

58. Ulku, H. (2004). R\&D, Innovation, and Economic Growth: An Empirical Analysis. IMF Working Paper No.04/185. Washington, DC: International Monetary Fund

59. Uvarova, I., \& Vitola, A. (2019). Innovation challenges and opportunities in European rural SMEs. Public Policy and Administration, 18(1), 152-166. https://doi.org/10.5755/j01.ppaa.18.1.23134

60. Venkatraman, M. P. (1991). The impact of innovativeness and innovation type on adoption. Journal of Retailing, 67(1), 51-67. 
61. Wang, C., Kafouros, M., Yi, J., Hong, J., \& Ganotakis, P. (2020). The role of government affiliation in explaining firm innovativeness and profitability in emerging countries : Evidence from China. Journal of World Business, 55(3), 101047. https://doi.org/10.1016/j.jwb.2019.101047

62. Wang, C. L., \& Ahmed, P. (2017). The Development and Validation of the Organizational Innovativeness Construct Using Confirmatory Factor Analysis. European Journal of Innovation Management, 7(4), 303313. https://doi.org/10.1108/14601060410565056

63. Wang, L., Luo, G., Sari, A., \& Shao, X. (2020). Technological Forecasting \& Social Change What nurtures fourth industrial revolution? An investigation of economic and social determinants of technological innovation in advanced economies. Technological Forecasting \& Social Change, 161(September), 120305. https://doi.org/10.1016/j.techfore.2020.120305

64. Wellalage, N. H., \& Fernandez, V. (2019). Innovation and SME finance: Evidence from developing countries. International Review of Financial Analysis, 66(July), 101370.

https://doi.org/10.1016/j.irfa.2019.06.009

65. Yachmeneva, V., \& Vol's'ka, G. (2014). Factors influencing the enterprise innovation. An International Quarterly Journal, 1(1), 133-138. http://ena.Ip.edu.ua

66. Yadollahi Farsi, J, \& Toghraee, M. (2014). Identification the main challenges of small and medium sized enterprises in exploiting of innovative opportunities (Case study: Iran SMEs). Journal of Global Entrepreneurship Research, 4, 4.

67. You, S., Zhou, K. Z., \& Jia, L. (2021). How does human capital foster product innovation? The contingent roles of industry cluster features. Journal of Business Research, 130(March), 335-347. https://doi.org/10.1016/j.jbusres.2021.03.046

68. Zanello, G., Fu, X., Mohnen, P., \& Ventresca, M. (2016). the Creation and Diffusion of Innovation in Developing Countries: a Systematic Literature Review. Journal of Economic Surveys, 30(5), 884-912. https://doi.org/10.1111/joes.12126

69. Zawawi, N. F. M., Mamun, A. Al, Wahab, S. A., Yaacob, A. S., Kumar, N., \& Fazal, S. A. (2016). Defining the Concept of Innovation and Firm Innovativeness : A Critical Analysis from Resorce-Based View Perspective Defining the Concept of Innovation and Firm Innovativeness : A Critical Analysis from Resorce-Based View Perspective. International Journal of Business and Management, 11(6). https://doi.org/10.5539/ijbm.v11n6p87

\section{Supplementary Files}

This is a list of supplementary files associated with this preprint. Click to download.

- AppendicesAdditinalfile.docx 